\title{
1 Rac1 controls cell turnover and mammary gland reversibility in
}

\section{2 post-partum involution.}

3

4 Aleksander Mironov ${ }^{1 \#}$, Matthew Fisher ${ }^{2 \#}$, Randa Elsayed ${ }^{2 \#}$, Melis Karabulutoglu ${ }^{2 \#}$ and $5 \quad$ Nasreen Akhtar ${ }^{2,3}$.

6

$7 \quad{ }^{1}$ Faculty of Biology Medicine and Health, University of Manchester, Oxford Rd, Manchester, 8 M13 9PT

$9{ }^{2}$ The Bateson Centre and Department of Oncology and Metabolism, University of Sheffield, 10 Sheffield, S10 2RX

${ }^{3}$ Correspondence:

n.akhtar@sheffield.ac.uk, tel +44 1142159059.

${ }^{\#}$ Authors contributed equally.

Condensed title: Rac1 control of mammary gland involution

Abbreviations: $\mathrm{WT}=\mathrm{WT}, \mathrm{MEC}=$ mammary epithelial cell. 


\section{$21 \quad$ Abstract}

Cell turnover in adult tissues is essential for maintaining tissue homeostasis over a lifespan and for inducing the morphological changes associated with the reproductive cycle. However, the underlying mechanisms that coordinate the balance of cell death and proliferation remain unsolved. Using the mammary gland we have discovered that Rac1 acts as a nexus to control cell turnover. Post-lactational tissue regression is characterized by the death of milk secreting alveoli, but the process is reversible within the first $48 \mathrm{~h}$ if feeding recommences. In mice lacking epithelial Rac1, alveolar regression was delayed. This defect did not result from failed cell death but rather increased cell turnover. Fitter progenitor cells inappropriately divided, regenerating the alveoli but cell death also concomitantly accelerated. We discovered that progenitor cell hyperproliferation was linked to non-autonomous effects of Rac1 deletion on the macrophageal niche with heightened inflammation. Moreover, loss of Rac1 impaired cell death with autophagy but switched the cell death route to apoptosis. Finally, mammary gland reversibility failed in the absence of Rac1 as the regenerated alveoli failed to recommence lactation upon re-suckling.

Key words: Mammary, Rac1, involution, cell turnover, autophagy, inflammation, reversible phase. 


\section{Introduction.}

Cell turnover in adult tissues is characterized by the death of older cells and replacement with new through stem and progenitor cell proliferation. How these processes are balanced to maintain long-term tissue homeostasis is not clearly understood. The mammary gland is an example of a tissue that maintains a state of flux throughout the adult life. It also undergoes periods of profound growth and regression in each reproductive cycle, providing a tractable model to study cell turnover. The primary role of the mammary gland is to produce milk as a source of nutrients to feed the newborn. Successful lactation depends on the coordinated development and differentiation of the secretory alveolar epithelium during pregnancy and the subsequent removal of these milk-producing units once the milk supply is no longer needed. The balance of cell death and cell division continuously alters to permit tissue growth and regression within the mammary gland reproductive cycle but little is known about how this is coordinated.

Weaning of the infants triggers the mammary gland to enter post-lactational involution, a process in which the surplus milk secreting alveolar epithelium is pruned from the ductal tree using a controlled cell death program (1). In rodents, $90 \%$ of the alveolar epithelium laid down in pregnancy is subsequently removed during involution, with the balance of cell death exceeding cell proliferation and the remodeling process completed within approximately two weeks. In dairy animals and humans, the involution process is slower, although cell death occurs, much of the alveolar structure is maintained, either through possible dedifferentiation of existing cells or through cell turnover $(2,3)$. In murine models of forced involution, simultaneous weaning of the pups at the peak of lactation causes the secretory alveoli to become engorged with milk as production continues for the first $24 \mathrm{~h}$, after which they dedifferentiate. Both mechanical stretch and milk factors have been reported to stimulate cell death $(1,4)$. A number of programmed cell death mechanisms have been identified in postlactational involution, including apoptosis, lysosomal permeabilisation and cell death with autophagy, although the significance of the different death pathways is unclear (5-7). 
69

0

Moreover, lysosomal permeabilisation and autophagy may feed into an apoptotic death downstream. Involution occurs in two phases; In the first $48 \mathrm{~h}$, cell death is triggered but the process of involution is reversible and the gland can re-initiate lactation once suckling resumes $(5,8)$. The second phase is irreversible and is characterized by destruction of the subtending basement membrane, extensive alveolar cell death and repopulation of stromal adipocytes. The dead cells and residual milk are primarily removed by neighbouring live alveolar mammary epithelial cells (MEC) that act as phagocytes (9-12). Engulfment of milk fat by the non-professional MECs triggers lysosomal permeabilisation through a stat-3 dependent mechanism, which ultimately kills the cells (12). In the second phase, professional phagocytes from the immune system enter the gland to engulf the remaining dead cells and the tissue remodels back to a state closely resembling the nulliparous gland $(13,14)$

We previously showed that the Rac1 GTPase plays a crucial role in post-lactational mammary gland remodeling(9). Rac1 is central to the conversion of mammary epithelial cells into non-professional phagocytes for the removal of dead cells and surplus milk and in controlling the inflammatory signature. We now reveal completely new roles for Rac1 in controlling the involution process. We have discovered that Rac1 acts as a nexus, controlling both the rate and balance of cell death and progenitor cell division in involution. Without Rac1 cell turnover accelerates with major consequences on mammary gland reversibility in the first phase of involution. Rac1 therefore has multifaceted roles in orchestrating the involution process. 
92

\section{Results}

Delayed alveolar regression and repopulation of adipocytes in involuting Rac1-/- mammary glands.

Mammary gland remodeling in involution is accompanied by alveolar regression and concomitant fat pad repopulation in the surrounding parenchyma. To investigate the role of Rac1 in tissue regression during involution we examined mammary tissues from female mice triggered to involute through simultaneous weaning of the pups. The Rac1 gene was deleted specifically in luminal cells of the mammary gland using Rac1 $1^{f / f t}: L S L Y F P: W A P i C r e$ (Rac1-/-) conditional knockout mice previously generated (15). Cre negative Rac1 ${ }^{f / f l}:$ LSLYFP littermates were used as WT controls (WT). Analysis of the WT mammary glands by histology revealed significant lobular alveolar regression and adipocyte repopulation between involution days 2-4 (Fig 1A,C,E,G,I and Fig S1). By contrast alveoli in Rac1-/glands remained distended with virtually no adipocyte repopulation (Fig 1B,D,F,H,I and Fig S1). Four weeks post-involution the alveoli had completely regressed in both WT and Rac1/- glands confirming that lobular alveolar cell death had occurred in the absence of Rac1 (Fig $1 \mathrm{~J})$.

B1-integrin is not upstream of Rac1 in alveolar regression.

In mammary gland tissue, $\beta 1$-integrin functions upstream of Rac1 to regulate lactational differentiation, stem cell renewal and cell cycle progression $(9,16-19)$, we thus investigated whether $\beta 1$-integrin was linked to alveolar regression in involution. The $\beta 1$-integrin gene was deleted in luminal cells of the mammary gland using $\beta 1$-integrin ${ }^{f / f t}:$ LSLYFP:WapiCre conditional knockout mice. Crucially, tissue analysis at involution days 2 and 4 revealed that loss of $\beta 1$-integrin did not impair alveolar regression and adipocyte repopulation compared to WT mice of a Cre negative genotype $\left(\beta 1\right.$-integrif ${ }^{f / f l}: L S L Y F P ;$ Figure $\left.2 A-E\right)$. This indicates that Rac1's role in tissue regression is elicited through a distinct upstream signaling axis. 

regression.

For effective removal of surplus alveoli the balance of cell death should exceed cell proliferation. We first investigated whether there was an initial delay in cell death in Rac1-/glands, which might explain the delay in alveolar regression. At involution day 4 where the delayed regression is most prominent, numerous cell corpses were evident in Rac1-/- glands both within the alveolar epithelium and within the lumen space (Figure 3A). We confirmed the dead cells with cleaved caspase -3 staining and that they were of luminal cell origin with the Rosa:LSL-YFP reporter gene which is activated in response to WAPiCre induced recombination (Figure 3B,C). Moreover, cell death was not delayed at earlier involution stages (day 2), but rather increased cell corpses were detected in Rac1-/- tissue lumens (Figure 3D,E). However, this might be a result of defective clearance by epithelial phagocytes as opposed to increased cell death in Rac1-/- glands (9). Thus the delay in alveolar regression in transgenic glands is not linked to impaired cell death.

Retention of milk within the lumens might contribute to the distended alveolar phenotype in Rac1-/- glands, since Rac1 is crucial for epithelial cell-directed engulfment of apoptotic cell corpses and residual milk(9). However, given the extensive cell death detected in early involution it was surprising that the alveoli remained intact. We thus investigated whether Rac1-/- alveoli were being maintained through cell renewal. Ki67 staining revealed almost no detectable proliferation in WT glands at involution day 4. In contrast Rac1-/- mammary glands showed extensive proliferation in both the ducts and alveoli (Figure 3F-H and Figure S2). Proliferation within the transgenic ducts continued at 4 weeks post-involution, at this stage however, most of the lobular alveoli had regressed (Figure $3 \mathrm{I}$ and $1 \mathrm{~J}$ ). Taken together these results suggest that the delayed alveolar regression in early involution in Rac1-/glands is linked to increased compensatory cell proliferation and not delayed apoptosis.

144 Thus Rac1 has a key role in balancing the rate of cell death and proliferation in involution by 145 limiting the division progeny of progenitors. Without Rac1 alveolar progenitors divide unexpectedly in involution. The newly replaced cells however, have a limited lifespan and 
147 succumb to death as evidenced by subsequent alveolar regression 4 weeks post-weaning

148 involution.

Loss of Rac1 elicits distinct proliferation responses within the first and second gestation.

Rac1 has been linked to cell cycle progression in numerous cultured cells and in vivo tissues(19-22). This is in complete contrast to our findings in vivo in the involuting mammary gland where loss of Rac1 induces proliferation. We thus examined the effects of Rac1 deletion on glandular development and proliferation within the first and second gestation. In the first gestation, wholemount analysis of mammary glands at pregnancy day 18 revealed slightly smaller alveoli in Rac1-/- glands (Figure 4A). However, immunostaining with Ki67 at lactation day 2 in the first cycle revealed no significant difference in proliferation between WT and Rac1-/- glands (Figure 4B,C). Moreover detection of the Rosa:LSL:YFP reporter gene revealed that recombination and thereby gene deletion was extensive and the proliferation was occurring within YFP positive/Rac1-/- cells and not from cells that had escaped recombination (Fig 4B).

In marked contrast to the involuting gland, within the second lactation cycle at day 2 , there was a severe block in proliferation of luminal cells with concomitant reduced lobular alveolar development in both late pregnancy and early lactation stages (Figure 4D-F, Fig S3). Taken together, these data show that Rac1 deletion has no effect on proliferation within the first lactation, heightened proliferation in post-lactational involution and severely defective proliferation within the second lactation. The disparity in proliferation profiles suggests stage-specific cell autonomous and possible non-autonomous regulation by Rac1.

Increased proliferation in involuting Rac1-/- glands is linked to inflammatory signals.

171 To explain the contrasting effect on cell proliferation within different stages of the mammary gland cycle, we sought to investigate possible cell non- autonomous effects of Rac1. We

173 previously showed heightened inflammatory responses in Rac1-/- mammary glands in post174 lactational involution(9). Heightened inflammation has been linked to altered epithelial 
175 proliferation and pathogenesis within numerous tissues including the gut and skin we thus 176 sought to investigate whether altered inflammatory responses without Rac1 were linked to 177 the increased proliferation. To test this we first examined for presence of inflammatory 178 signals within in the gestational stage and in involution. In the first gestation, Rac1 deletion 179 did not induce inflammatory signals (Figure 5A, C,D) and this correlates with no significant difference in proliferation (Fig 4B,C). In contrast in involution Rac1 deletion heightens inflammatory signals with early macrophage recruitment (9) (Figure 5B-D) and this correlates with elevated proliferation (Figure $3 \mathrm{~F}-\mathrm{H}$ ). To remove possible impending signals from inflammatory cells, pure populations of mammary epithelia were isolated from $R a c 1^{f l / f I} C r e E R^{T M}$ mice and the Rac1 gene was ablated in culture with 4-hydroxytamoxifen. At this stage greater than $90 \%$ of the cells are alveolar in origin. Loss of Rac1 impaired proliferation in 3D organoids on a basement membrane matrix (Figure 5E-G). Moreover ductal cultures from nulliparous $\operatorname{Rac} 1^{f / f l} \mathrm{Cre}^{\mathrm{f}} R^{T M}$ mammary glands failed to branch out in the absence of Rac1 (Figure 5F). Together, these data suggest that increased proliferation in involution in Rac1-/- glands is in part driven through secondary non-cell autonomous effects of Rac1 deletion and is connected to heightened and sustained inflammatory responses. These findings reveal that Rac1 mediates a functionally important cross-talk between mammary gland cells and immune phagocytes within their microenvironmental niche.

Rac1 directs cell death with autophagy but not apoptosis or necrosis.

As cell death and inflammation are intermittently linked, we examined the effects of removing Rac1 on the cell death route in involution. Ultrastructural studies in day 2 and 4 , involuting glands revealed numerous vacuolar structures in WT alveolar epithelium but not Rac1-/- transgenics (Figure 6A,G,M,O). Further analysis revealed autophagosomes, autolysosomes and lysosomes in the WT alveolar epithelium, suggestive of cell death with autophagy (Figure 6A-C, M,N). Moreover, we detected numerous phagosomes with engulfed milk proteins, milk lipid droplets and dead cells (Figure 6D-F), which supports are 
cells(9). In contrast Rac1-/- alveoli were completely void of both autophagososmes and

204 phagosomes, instead we detected either live cells or dead cells shed into the lumen with apoptotic morphology and some necrotic cells with ruptured membranes and organelles released extracellularly (Figure 6G-L,O,P). We further confirmed autophagy in WT glands by immunostaining for the essential autophagy related LC3 $\beta$ protein, which appeared punctate and therefore indicative of translocation to the autopagososme membrane. In contrast, LC3 $\beta$ staining was diffuse in Rac1-/- transgenics confirming the absence of autophagosomes (Figure 6Q, R). Consistent with the ultrastructural studies, gene array analysis revealed down-regulation of genes associated with autophagososme and lysosomal pathways (Figure 6S). Whole groups of lysosomal hydrolases, including proteases, glycosidases, sulfatases, DNases and lipases were down-regulated in Rac1-/- transgenics

214 (Table S1). Taken together these data show that Rac1 is required to induce cell death with autophagy but without Rac1 cells can still die via apoptosis and necrosis. The presence of necrotic cells likely contribute to the heightened inflammatory responses in Rac1-/- glands.

Cell death is accelerated without Rac1.

219 We next investigated whether necrotic cells occurred secondary to apoptosis as a result of defective phagocytosis or whether loss of Rac1 triggers a programmed necrotic cell death. To test this directly, primary cultures of WT and Rac1-/- cells were induced to undergo anoikis, a detachment induced cell death. We chose this method of cell death for two reasons, first, to prevent dying cells from removal by neighbouring non-professional phagocytosis, as single cells suspended in media are spatially out of reach for phagocytic removal and second to trigger an innate programmed cell death rather than chemicalinduced. Dying cells incorporated higher levels of propidium iodide (PI) in the absence of Rac1 compared to WT controls, suggesting cell death by necrosis or late stage apoptosis (Figure $7 A, B)$. To establish the proximal cell death route, we first examined for hallmarks of 
and Rac1-/- cell corpses displayed intact membranes with nuclear condensation, late stage membrane blebbing, body fragmentation and stained positive for cleaved caspase 3 indicative of an apoptotic cell death (Figure $7 C-G$ and $3 B, E$ ). Early stage apoptosis is characterized by phosphatidylserine exposure to the outer membrane leaflet and Annexin $\mathrm{V}$ is commonly used to detect this motif. Co-labelling with annexin $\mathrm{V}$ and $\mathrm{PI}$ in cells suspended for $1 \mathrm{~h}$ and $5 \mathrm{~h}$ revealed that approximately the same number of cells enter apoptosis with and without Rac1, (Annexin $\mathrm{V}$ only) however, by $5 \mathrm{~h}$ significantly more Rac1-/- cells proceed to late stage apoptosis/necrosis (Annexin $\mathrm{V} / \mathrm{PI}$ ) with a concomitant reduction in numbers in early stage apoptosis (Annexin $\mathrm{V}$ only; Figure $7 \mathrm{H}$ ). Moreover, the numbers of viable cells declined following $8 \mathrm{~h}$ suspension in the absence of Rac1 indicating that cells had proceeded through death and disintegrated within this time frame compared to WT controls (Figure 7I, J).

As Annexin $\mathrm{V}$ can also bind necrotic cells with ruptured membranes, some of the cells in the Annexin V/PI fraction may be a result of primary necrosis. To investigate primary necrosis we analysed the nuclei of necrotic cell corpses by electron microscopy. In Rac1-/- glands, the nuclei of ruptured cells were not condensed, suggesting they had not entered the apoptotic pathway first, but rather died through primary necrosis (Figure $7 \mathrm{~L}$ ). Organelle spillage and cell necrosis was also detected in Rac1-/- primary cultures (Figure 7N). In contrast WT dead cells had intact membranes with nuclear condensation (Figure 7K,M). These studies reveal that Rac1 slows down the process of programmed cell death. Without Rac1, cells die either through primary necrosis or through apoptosis but the apoptotic death proceeds more rapidly than in WT epithelia. Taken together, loss of Rac1 increases cell turnover rates in the involuting mammary gland through both increased progenitor proliferation and accelerated cell death.

Lactation fails to resume upon pup re-suckling in involuting Rac1-/- glands.

256 To determine the functional consequences of the increased cell turnover in Rac1-/- glands, 257 we investigated the reversible phase of the involution process. Nursing WT and Rac1-/- 
258 dams were separated from the pups for $48 \mathrm{~h}$ to stimulate the first phase of involution and 259 then reunited for a $24 \mathrm{~h}$ period. Re-suckling in the WT mammary glands recommenced 260 lactation as detected by an approximate 18-fold increase in casein 2 gene expression and 261 the alveolar epithelium resumed a lactation morphology (Figure 8A, C). In contrast the 262 Rac1-/- glands failed to lactate and the involution morphology persisted with dead cell 263 shedding into the lumen (Figure 8B, C). Whilst a small increase in milk protein gene expression was detected in re-suckled Rac1-/- glands compared with the involuting Rac1-/-,

265 the casein gene expression was 18 -fold less than the WT fed gland. This compromise in 266 milk protein expression is significantly greater than the 2 -fold decrease detected in the first 267 lactation cycle where Rac1-/- dams are still able to support pups (9). Together these data 268 indicate that Rac1 is crucial for mammary gland reversibility in phase I of the involution 269 process upon re-suckling. Without Rac1, cell turnover rates increase in early involution but the newly replenished alveoli lose the ability to recommence lactation. 


\section{Discussion}

274 Our study reveals that Rac1 acts as a central nexus in controlling the balance of cell death 275 and proliferation within the mammary gland and is critical for mammary gland reversibility in early involution. The mammary gland removes approximately $90 \%$ of its tissue weight in post-lactational involution with mass destruction of the milk secreting alveolar units. This extensive regression can only be accomplished if the balance tips towards cell death with reduced proliferation. We have discovered that cell proliferation actively stops in involution and this is a Rac1-mediated process. Removal of Rac1 induces extensive proliferation within the involuting gland. We show the initial delay in alveolar regression is a result of compensatory cell renewal within alveoli and not a delay in cell death. The newly replaced cells in alveoli, however, have a short lifespan as the mammary alveoli regressed by 4 weeks post-weaning. A previous study also reported a delay in Rac1-/- alveolar regression but attributed the effects to delayed cell death (23). In contrast our data show that cell death is not blocked in Rac1-/- alveoli in early involution as we have detected numerous cell corpses using both light and electron microscopy.

The involution process is accompanied by inflammatory cell influx to remove residual dead corpses by phagocytosis, increased matrix metalloproteinase activity, extracellular matrix remodeling with subsequent release of various morphogens $(13,24)$. It is well established that pro-inflammatory signals invoke stem cell proliferation in several disease models including psoriasis and various cancers. The involution microenvironment is known to support breast cancer growth in tumour mouse models and promote postpartum breast cancer in women $(24,25)$. We have made the important discovery that one mechanism by which the postpartum involuting mammary gland protects itself from inflammation-induced proliferation is through the Rac1 GTPase. Consequently healthy mammary epithelial progenitor cells resist proliferating in a tumour promoting microenvironment. Loss of Rac1 increases pro-inflammatory signals in the mammary gland, thereby stimulating cell proliferation. Interestingly in the skin, loss of Rac1 also causes stem cell release through 
activation of c-myc, although this study did not investigate inflammatory responses (26).

Whether Rac1 promotes or suppresses cell proliferation appears to be dependent on the microenvironmental context. Rac1 is linked to stem cell renewal and cell cycle progression in mammary epithelia and in numerous other models $(17,19-22)$. We have now shown that

Rac1 genetic deletion perturbs proliferation in purified epithelial organoid cultures void of impending inflammatory cells. This suggests both cell autonomous and non-autonomous regulation of proliferation by Rac1 depending on the environmental context. In addition to heightened inflammatory signals, stagnant milk in Rac1-/- mammary gland structures might cause stretch-induced proliferation. Indeed ductal and alveolar bloating is severe in Rac1-/glands because of defective clearance by MEC phagocytes.

Upstream of Rac1, $\beta 1$-integrin has been linked to stem cell renewal, cell cycle progression and lactational differentiation in mammary epithelia $(16,18,19,27,28)$. Here we demonstrate that in involution, Rac1 controls alveolar regression independently of $\beta 1$ integrin. This suggests distinct upstream wiring allows Rac1 to perform multifaceted roles within the mammary gland. The Rac guanine nucleotide exchange factors (GEFs) ELMO and Dock180 also show delayed alveolar regression in involution but the receptor that activates these GEFs remains to be identified (23).

317 Our data show that alveolar epithelial cells die through distinct mechanisms with and without

318 Rac1. Multiple cell death mechanisms have been reported in mammary gland involution, 319 including autophagy and lysosomal leakiness linked to milk fat engulfment $(6,7,29)$. We discovered that in the absence of Rac1, cell death with autophagy is impaired, milk phagocytosis is impaired (9) with a concomitant lack of detectable lysosomes by EM and down-regulation of several lysosomal genes. Despite these deficiencies, Rac1-/- cells still die through both apoptotic and necrotic mechanisms and there is no delay in cell death.

324 These alternate routes ensure a protective redundancy that enables cell death to proceed. Of interest is that in the autophagy defective Beclin 1-/- mammary glands, Rac1 activation is perturbed, which suggests a regulatory feedback loop (7). 
327 We have discovered that in addition to increased proliferation, apoptosis accelerates without

328 Rac1, thereby Rac1 critically functions to limit cell turnover rates in involution. We have

329 identified this as an important self-regulatory mechanism that enables mammary gland

330 reversibility within the first $48 \mathrm{~h}$ of involution. Despite cell renewal within Rac1-/- alveoli in

331 early involution, the replaced cells cannot lactate upon re-suckling. This suggests a mechanism by which existing cells resist cell death to allow reversibility. One such mechanism is autophagy, which might act as a survival mechanism in early involution

334 instead of cell death. Ultimately the replaced cells in Rac1-/- alveoli also succumb to death

335 as the gland regressed 4 weeks post-weaning involution. The lactation defect, however, is

336 long-term, as we have previously demonstrated severely defective future lactations in Rac1-

337 /- mammary glands (9). Future studies will focus on how perturbing Rac1 alters the luminal stem/progenitor niche leading to defective alveolar lineages and long-term tissue malfunction in successive gestations. 
Methods

Mice

347 The $\operatorname{Rac1}^{f / f / t}: Y F P ; W A P i C r e^{T g / \cdot}$ and $\operatorname{Rac1}^{f / f f l} ;$ CreER $^{T M}$ mice were as previously described (15).

348 For the in vivo analysis, the WAPiCre promoter, which is activated mid-late pregnancy was 349 used for $R a c 1^{f / f f l}$ gene deletion specifically in luminal mammary epithelial cells.

350 Rosa:LSL:YFP reporter gene was used to detect Cre-induced recombination of flox alleles.

$351 R a c 1^{f / f l}:$ YFP littermates that lacked the Cre gene were used as WT controls. The genotypes

352 of offspring were determined by PCR amplification of ear DNA as in (15).

$353 R$ Rac1 $1^{f / f f}: Y F P ; C r e E R^{T M}$ mice were used for inducible deletion of the Rac1 gene in primary

354 cultures. Female mice were mated between 8 and 12 weeks of age. $\beta 1$-integrin ${ }^{\text {ff/tl: }}$

355 YFP:WAPiCre mice were generated by crossing $\beta 1$-integrin ${ }^{f f l}$ mice; JAX \#004605 (30) with

356 WAPiCre:YFP mice previously described (9). For involution studies, dams were allowed to

357 nurse litters (normalized to 6-8 pups) for 7-10 days and then pups were weaned to initiate

358 involution. In the involution rescue experiments, breeding trios were set up with a male, an experimental female and a WT surrogate female. Impregnated females were separated

360 from the male, allowed to litter and nurse offspring jointly as above. Experimental dams were separated for $48 \mathrm{~h}$ to involute, while the surrogates continued feeding the pups. Litters were subsequently reunited with the experimental female for a period of $24 \mathrm{~h}$ prior to gland harvesting. 3- 6 mice per group were analysed for each developmental stage. Mice were housed and maintained according to the UK Home Office guidelines for animal research.

\section{Histology}

367 Mammary tissue was formalin fixed $(4 \% \mathrm{v} / \mathrm{v})$, paraffin embedded before sectioning $(5 \mu \mathrm{m})$

368 and subjected to standard haematoxylin and eosin (H\&E) staining. Histology was imaged 369 using 3D Histotec Pannoramic 250 slide scanner and Aperio ImageScope version 12.1 software. Adipocytes were quantified using Fiji/ImageJ adiponectin software plug-in. 
371 Whole mount analysis was performed by spreading inguinal mammary glands on polysine

372 slides and stained with carmine alum as previously described (27). Glands were imaged

373 using a Nikon SMZ18 stereoscope.

374

375

TEM

376

Involuting mammary tissues were fixed with $4 \%$ formaldehyde $+2.5 \%$ glutaraldehyde in

$0.1 \mathrm{M}$ Hepes buffer $(\mathrm{pH} 7.2)$ for 1 hour. Post-fixed with $1 \%$ osmium tetroxide $+1.5 \%$

378 potassium ferrocynaide in $0.1 \mathrm{M}$ cacodylate buffer $(\mathrm{pH} 7.2)$ for 1 hour, in $1 \%$

379 thyocarbohydrazide in water for $20 \mathrm{~min}$, in $2 \%$ osmium tetroxide in water for $30 \mathrm{~min}$, followed

380 by $1 \%$ uranyl acetate in water for overnight. The next day tissues were stained with Walton

381 lead aspartate for 1 hour at $60^{\circ} \mathrm{C}$ degree, dehydrated in ethanol series infiltrated with TAAB

382812 hard grade resin and polymerized for $24 \mathrm{~h}$ at $60^{\circ} \mathrm{C}$ degree. TEM sections were cut with

383 Reichert Ultracut ultramicrotome and observed with FEI Tecnai 12 Biotwin microscope at

$384100 \mathrm{kV}$ accelerating voltage. Images were taken with Gatan Orius SC1000 CCD camera.

385

RNA isolation and cDNA synthesis

387

RNA was isolated from the $4^{\text {th }}$ inguinal mammary gland using Trifast reagent (Peqlab)

according to manufacturer's instructions. $2 \mu \mathrm{g}$ of RNA was used to prepare cDNA using the

high capacity RNA to cDNA kit (Invitrogen) according to manufacturer's instructions.

390

391

\section{Affymetrix gene array}

392 Gene arrays were conducted previously(9), Data accession: E-MTAB-5019 (Array Express) 393 or GSE85188 (GEO). Gene lists were analysed using DAVID, Panther and GSEA web 394 accessible programs.

\section{Quantitative RT-PCR}

QRT-PCR was performed on the Applied Biosystems 7900HT using the following Taqman 
(Mm00442479_m1) as house-keeping genes, CCL2 (Mm00441242_m1), CCL7

400 (Mm00443113_m1), Csn2 (Mm04207885_m1). Thermal cycling conditions were: UNG start at $50^{\circ} \mathrm{C}(2 \mathrm{~min}), 95^{\circ} \mathrm{C}(10 \mathrm{~min})$ and then 40 cycles of $95^{\circ} \mathrm{C}(15 \mathrm{sec})$ followed by annealing at $60^{\circ} \mathrm{C}(1 \mathrm{~min})$.

403

\section{Primary cell culture and gene deletion}

405 Primary MECs were harvested from either 15.5-17.5 day pregnant mice for alveolar cultures or 12 week old virgin mice for ductal cultures and cultured as described in (31).

Cells were plated onto Collagen 1 for monolayer cultures or basement membrane-matrix (Matrigel; BD Biosciences) to form acini and cultured in growth media (Ham's F12 medium (Sigma) containing $5 \mu \mathrm{g} / \mathrm{ml}$ insulin, $1 \mu \mathrm{g} / \mathrm{ml}$ hydrocortisone (Sigma), $3 \mathrm{ng} / \mathrm{ml}$ epidermal growth factor (EGF), 10\% fetal calf serum (Biowittaker), $50 \mathrm{U} / \mathrm{ml}$ Penicillin/Streptomycin, $0.25 \mu \mathrm{g} / \mathrm{ml}$ fungizone and $50 \mu \mathrm{g} / \mathrm{ml}$ gentamycin). For ductal branching cells were cultured in branching medium (DMEM- F12 medium (Lonza) containing insulin-transferrin-selenium G supplement (100x), 2nM hb-fibroblast growth factor (Sigma cat: F0291) and $50 \mathrm{U} / \mathrm{ml}$ Penicillin/Streptomycin). For inducible Rac1 gene ablation, MEC cultures were prepared from Rac1 ${ }^{f / f f l} ; C$ CreER $R^{T M}$ mice, and treated with $100 \mathrm{nM}$ 4-hydroxytamoxifen dissolved in ethanol. For proliferation assays, $10 \mu \mathrm{M}$ EdU was added for $2 \mathrm{~h}$ to either day 2 or day 3 cultures and developed using the Click-IT EdU Alexa Fluor imaging kit (Life Technologies).

\section{Anoikis assays and FACS.}

Apoptotic MECs $(-/+4 \mathrm{OHT})$ were prepared in suspension culture for either $1 \mathrm{~h}$ or $5 \mathrm{~h}$, in serum-free media (DMEM-F12 containing $2.5 \mu \mathrm{g} / \mathrm{ml}$ insulin). Cells were labelled with propidium iodide and/or Alexa Flour 647-Annexin $\vee$ (Biolegend) according to manufacturer's instructions and analysed by flow cytometry or cytospun onto polysine slides, fixed and counterstained with hoechst for micrographs. Some cytospun suspension cultures were stained with cleaved caspase-3 antibody. 
427 Immunostaining.

428 Expression and distribution of various proteins were visualised by indirect

429 immunofluorescence. Cells were fixed for $10 \mathrm{~min}$ in PBS / 4\% (w/v) paraformaldehyde, and 430 permeabilised for 7 min using PBS / 0.2\% (v/v) Triton X100. Non-specific sites were blocked 431 with PBS / 10\% goat serum (1h, RT) prior to incubation with antibodies diluted in PBS / 5\% 432 goat serum (1h, RT, each). EdU was detected using the Click-iT EdU Alexa Fluor 647 433 imaging kit (Life Technologies) and nuclei were stained using $4 \mu \mathrm{g} / \mathrm{ml}$ Hoechst 33258 434 (Sigma) for $5 \mathrm{~min}$ at RT. Cells were washed in PBS before mounting in prolong gold antifade 435 (Molecular Probes). Images were collected on a Nikon A1 confocal or a Leica TCS SP5 436 AOBS inverted confocal as previously described (15). Non-biased cell counts were 437 performed by concealing the identity of each slide.

438 Immunostaining of mammary tissue was performed on paraffin-embedded tissue (5um) or cryosections $(10 \mu \mathrm{m})$ and luminal surface was detected with wheat germ agglutinin-488, or 647 (Invitrogen, \#W11261, \#W32466) and imaged using confocal microscopy. Primary antibodies used for immunofluorescence are indicated in Supplementary table 2. Secondary 442 antibodies were conjugated to Cy2, Alexa-488, Rhodamine-RX, Cy5, Alexa-647 (Jackson 443 Immunoresearch) and horse-radish peroxidase.

\section{Protein analysis}

446 Proteins were extracted as in (16). Equal amounts of proteins were used and equivalent 447 loading assessed by referral to controls, such as Calnexin (Bioquote SPA-860) or E448 cadherin (Cell Signalling \#610182). Primary antibodies used for immunoblotting are 449 indicated in Supplementary table 2. ImageJ was used to quantify bands. 


\section{Author contribution.}

453 NA conceived ideas, performed most of the experiments and wrote the manuscript. MF, RE

454 and MK contributed experiments, AM performed the electron microscopy.

455

456 Acknowledgements

457 We thank Karen-Piper Hanley (University of Manchester) for the $\beta 1$-integrin ${ }^{\text {ffll }}$ mice. This 458 work was supported by the Thomas, Berry and Simpson fellowship (N.A), Wellcome Trust $459 \quad \# 200588 / Z / 16 / Z$ (N.A) and Medical Research Council; MR/P028411/1 (N.A).

460 The authors declare no financial or conflicts of interest related to this manuscript.

461

462

463

464

465 


\section{References}

467

468

1. Watson CJ. Involution: apoptosis and tissue remodelling that convert the mammary gland from milk factory to a quiescent organ. Breast Cancer Res. 2006;8(2):203.

470

2. Dessauge F, Lollivier V, Ponchon B, Bruckmaier R, Finot L, Wiart S, et al. Effects of 472 nutrient restriction on mammary cell turnover and mammary gland remodeling in lactating dairy cows. Journal of Dairy Science. 2011;94(9):4623-35.

474

475

3. Sonali Jindal DG, , Pat Bell, Grethe Albrektsen, Susan M Edgerton, Christine B

Ambrosone, Ann D Thor, Virginia F Borges and Pepper Schedin. Postpartum breast involution reveals regression of secretory lobules mediated by tissue-remodeling. Breast Cancer Research. 2014;16(R31).

479

480

4. Quaglino A, Salierno M, Pellegrotti J, Rubinstein N, Kordon EC. Mechanical strain induces involution-associated events in mammary epithelial cells. BMC Cell Biology. 2009;10(1):55.

482

5. M Li XL, G Robinson, U Bar-Peled, K U Wagner, W S Young, L Hennighausen, P A Furth. Mammary-derived signals activate programmed cell death during the first stage of mammary gland involution Proc Natl Acad Sci U S A. 1997;94(7):3425-30.

487 6. Kreuzaler PA, Staniszewska AD, Li W, Omidvar N, Kedjouar B, Turkson J, et al. Stat3 controls lysosomal-mediated cell death in vivo. Nat Cell Biol. 2011;13(3):303-9.

489

490 7. Teplova I, Lozy F, Price S, Singh S, Barnard N, Cardiff RD, et al. ATG proteins mediate 491 efferocytosis and suppress inflammation in mammary involution. Autophagy. 2013;9(4):459- 
494 8. Lund LR, Romer J, Thomasset N, Solberg H, Pyke C, Bissell MJ, et al. Two distinct phases of apoptosis in mammary gland involution: proteinase-independent and -dependent pathways. Development. 1996;122(1):181-93.

497

9. Akhtar N, Li W, Mironov A, Streuli Charles H. Rac1 Controls Both the Secretory Function of the Mammary Gland and Its Remodeling for Successive Gestations. Developmental Cell. $2016 ; 38(5): 522-35$.

501

502

10. Hanayama R, Miyasaka K, Nakaya M, Nagata S. MFG-E8-dependent clearance of apoptotic cells, and autoimmunity caused by its failure. Curr Dir Autoimmun. 2006;9:162-72.

504

505

11. Monks J, Rosner D, Geske FJ, Lehman L, Hanson L, Neville MC, et al. Epithelial cells as phagocytes: apoptotic epithelial cells are engulfed by mammary alveolar epithelial cells and repress inflammatory mediator release. Cell Death Differ. 2005;12(2):107-14.

508

509

12. Sargeant TJ, Lloyd-Lewis B, Resemann HK, Ramos-Montoya A, Skepper J, Watson CJ.

Stat3 controls cell death during mammary gland involution by regulating uptake of milk fat globules and lysosomal membrane permeabilization. Nat Cell Biol. 2014;16(11):1057-68.

13. Atabai K, Sheppard D, Werb Z. Roles of the innate immune system in mammary gland remodeling during involution. J Mammary Gland Biol Neoplasia. 2007;12(1):37-45. 
522 16. Akhtar N, Streuli $\mathrm{CH}$. Rac1 links integrin-mediated adhesion to the control of lactational 523 differentiation in mammary epithelia. J Cell Biol. 2006;173(5):781-93.

524

17. Moreno-Layseca P, Ucar A, Sun H, Wood A, Olabi S, Gilmore AP, et al. The requirement of integrins for breast epithelial proliferation. European Journal of Cell Biology. 2017;96(3):227-39.

528

529

18. Naylor MJ, Li N, Cheung J, Lowe ET, Lambert E, Marlow R, et al. Ablation of beta1 integrin in mammary epithelium reveals a key role for integrin in glandular morphogenesis and differentiation. J Cell Biol. 2005;171(4):717-28.

532

533

19. Olabi S, Ucar A, Brennan K, Streuli CH. Integrin-Rac signalling for mammary epithelial stem cell self-renewal. Breast Cancer Research. 2018;20(1).

20. Jeanes Al, Wang P, Moreno-Layseca P, Paul N, Cheung J, Tsang R, et al. Specific betacontaining integrins exert differential control on proliferation and two-dimensional collective cell migration in mammary epithelial cells. The Journal of biological chemistry. 2012;287(29):24103-12.

540 accumulates in the nucleus during the $\mathrm{G} 2$ phase of the cell cycle and promotes cell division. J Cell Biol. 2008;181(3):485-96.

22. Vidaki M, Tivodar S, Doulgeraki K, Tybulewicz V, Kessaris N, Pachnis V, et al. Rac1dependent cell cycle exit of MGE precursors and GABAergic interneuron migration to the cortex. Cereb Cortex. 2012;22(3):680-92. 

gland involution in the absence of Dock1 and Rac1 signaling. Cell Death Dis. 2014;5:e1375.

24. Wallace TR, Tarullo SE, Crump LS, Lyons TR. Studies of postpartum mammary gland involution reveal novel pro-metastatic mechanisms. Journal of Cancer Metastasis and Treatment. 2019;2019.

555

25. Schedin P. Pregnancy-associated breast cancer and metastasis. Nature Reviews Cancer. 2006;6(4):281-91. dissection of integrin signalling proteins in the control of mammary epithelial development and differentiation. Development. 2009;136(6):1019-27.

28. Li N, Zhang Y, Naylor MJ, Franziska Schatzmann, Francisca Maurer, Tim Wintermantel, et al. b1 integrins regulate mammary gland proliferation and maintain the integrity of mammary. The EMBO Journal. 2005;24(11):1942-53. protein response (UPR) regulate mammary gland involution by restraining apoptosis-driven irreversible changes. Cell Death Discovery. 2018;4(1).

573

30. Raghavan S, Bauer C, Mundschau G, Li Q, Fuchs E. Conditional Ablation of $\beta 1$ Integrin Hair Follicle Invagination. The Journal of Cell Biology. 2000;150(5):1149-60. 
bioRxiv preprint doi: https://doi.org/10.1101/2022.02.28.482219; this version posted March 2,2022 . The copyright holder for this preprint

(which was not certified by peer review) is the author/funder, who has granted bioRxiv a license to display the preprint in perpetuity. It is made available under aCC-BY 4.0 International license.

578 31. Pullan S, Wilson J, Metcalfe A, Edwards GM, Goberdhan N, Tilly J, et al. Requirement of

579 basement membrane for the suppression of programmed cell death in mammary epithelium.

580 J Cell Sci. 1996;109 ( Pt 3):631-42.

581

582

583

584 


\section{$585 \quad$ Figure legends}

586

587 Figure 1: Delayed alveolar regression in Rac1 null glands in involution.

588 (A-D) Carmine staining of whole-mounted mammary glands of WT $(A, C)$ and Rac1-/- (B,D)

589 mice at post-lactational involution day 2 and day 4. Note the alveolar regression in WT but

590 not Rac1-/- glands at Involution day 4. Bar; $5 \mathrm{~mm}$, (inset $1 \mathrm{~mm}$ ).

591 (E-H) Haematoxylin and Eosin $(\mathrm{H}+\mathrm{E})$ stain shows alveolar regression and adipocyte

592 repopulation in WT glands $(E, G)$ but this is delayed in Rac1-/- glands $(F, H)$. Bar; 100um.

593 (I) Quantification of adipocyte repopulation. Error bars; $+/$ - SEM of $n=3$ mice. * $P=0.0043$

594 (J) Carmine staining of whole-mounted WT and Rac1-/- mammary glands at 4 weeks post595 lactational involution show complete regression of alveoli. Note; bloated ducts persist in 596 Rac1-/-glands. Bar; 0.7mm.

597

598 Figure 2: Ablation of $\beta 1$-integrin does not phenocopy the Rac1-/-involution phenotype.

599 (a-d) H+E stains at Involution day 2 and 4 show no delay in alveolar regression in $\beta 1$ 600 integrin-/- mice. Both WT glands $(a, b)$ and $\beta 1$-integrin-/- $(c, d)$ glands equally regressed.

601 Bar: $100 \mu \mathrm{m}$.

602

(e) Quantification of adipocyte repopulation. Error bars; +/- SEM of $n=4$ mice

603

604 Figure 3: Delayed alveolar regression is not due to impaired cell death but heightened 605 proliferation.

606 (A,D) H+E stain shows numerous dead cells in Rac1-/- alveolar lumens at Involution day 4 607 (A) and Involution day 2 (D). Bar; 40uM.

$608(B, E)$ Dead cells were confirmed in involution day 4 (B) and day 2 (E) glands by 609 immunofluorescence staining with cleaved caspase 3 (red) and Keratin (Krt) 8/18 (green) to 610 mark luminal cells. Note the Krt8-18 antibody cross reacts with intact keratins in live cells 
611 and not cleaved forms in dead cells. Arrow: caspase positive dead cells in the lumen. Bar;

$61240 \mu \mathrm{m}$.

613 (C) Dead cells in the lumen were confirmed to be of luminal origin with the YFP reporter

614 gene. GFP antibody was used to stain the YFP reporter gene. Arrowhead: dead cells in the

615 lumen. Bar; $20 \mu \mathrm{m}$.

$616(F, G)$ Immunofluorescence staining for proliferation marker Ki67 (red) reveals increased 617 proliferation within Rac1-/- glands at involution day 4 in alveoli (F, F') and ducts (G, G').

618 Epithelial tissue boundary was detected by smooth muscle actin (SMA, green) present in 619 myoepithelial cells. Bar; $50 \mu \mathrm{m}$.

$620(\mathrm{H})$ Quantitative analysis of Ki67 staining at involution day 4. 10 areas/mouse were analysed. Error bars: $+/-$ SEM of $n=3$ mice. $P=0.0029$.

622 (I) Proliferation persists in bloated Rac1-/- ducts 4 weeks postlactational-involution. Bar; $62350 \mu \mathrm{m}$.

624

625 Figure 4: Distinct proliferation in Rac1-/- mammary glands within the first and second 626 gestations.

627 (A) Carmine staining of whole-mounted mammary glands from WT and Rac1-/- mice at 628 pregnancy day 18 in the first gestation. Bar; $2.8 \mathrm{~mm}$ (insert $0.3 \mathrm{~mm}$ ).

629 (B) Immunoflourescence staining with Ki67 in WT and Rac1-/- glands shows no difference in 630 proliferation at lactation day 2 following the first gestation. Green fluorescent protein 631 antibody was used to detect the WapiCre driven YFP reporter gene expression and hence 632 Rac1 deletion. Arrows show proliferation in YFP positive/ Rac1-/-cells. Bar; 40um.

633 (C) Quantitative analysis of Ki67 staining at lactation day 2 following the first gestation 634 shows no significant difference between WT and Rac1-/- glands. 10 areas/mouse were 635 analysed. Error bars: +/- SEM of $n=4$ WT mice and $n=5$ Rac1-/- mice. $P>0.05$. 
636 (D) Carmine staining of whole-mounted mammary glands from WT and Rac1-/- mice at 637 pregnancy day 18 in the second gestation. Note the reduced lobular alveolar development.

638 Bar; 2.8mm (insert 0.3mm).

639 (E) Ki67 staining reveals reduced proliferation in Rac1-/- mammary glands at lactation day 2 640 following the second gestation. Bar; $40 \mu \mathrm{m}$.

641 (F) Quantitative analysis of ki67 positive staining in WT and Rac1-/- glands at lactation day 642 2, second gestation. 15 areas/ mouse were analysed. Error bars: +/- SEM of $n=4$ mice. * $643 \quad P=0.0051$

644

645 Figure 5: Rac1-/- hyperproliferation in involution is linked to inflammation.

$646(A, B)$ Immunoflourescence staining with F4:80 antibody (red) to detect macrophages in WT 647 and Rac1-/- glands at Lactation day 2 and Involution day 2. GFP antibody was used to 648 detect the YFP reporter gene expression. Error bars: +/- SEM of $n=3-4$ mice. Arrow; 649 macrophage in lumen of Rac1-/- alveoli. Bar; $40 \mu \mathrm{m}$.

650 (C,D) Quantitative RT-PCR shows elevated inflammatory chemokines CCL2 and CCL7 in 651 Rac1-/- glands at Involution day 2 but not in late pregnancy. ${ }^{*} \mathrm{P}=<0.025$.

652 (E) EDU incorporation in WT and Rac1-/- primary mammary alveolar organoids from $653 R a c^{f f l}$ CreERT mid-pregnant mice, cultured on a BM-matrix show reduced proliferation in the 654 absence of Rac1. Immunofluorescence staining with GFP antibody was used to detect the 655 YFP reporter gene expression (green) and EDU (magenta). Images are confocal sections 656 through the middle of the alveoli. Arrow: proliferation in YFP negative cells in Rac1-/657 organoid. Bar; $20 \mu \mathrm{m}$.

658 (F) Quantitative analysis of EDU incorporation reveals decreased proliferation in Rac1-/organoids. EDU incorporation was counted in YFP positive cells/Rac1-/- only in 4oht treated organoids. Error bars: $+/-$ SEM of $n=3$ experiments. 
(G) Depletion of Rac1 in primary MEC organoids was confirmed by immunoblotting cell

662 lysates prepared from control or 4oht treated cultures with a Rac1 antibody. Calnexin

663 antibody was used to show equal loading of protein.

664 (H) Ductal branching in WT and Rac1-/- organoids in response to FGF stimulation.

665 Depletion of Rac1 prevents outgrowth. Bar; $40 \mu \mathrm{m}$.

666

667

Figure 6: Rac1 mediates cell death with autophagy but not apoptosis.

668 Electron micrographs of WT (A-F) and Rac1-/- (G-L) involution day 2 glands.

669 (A,) WT alveolus showing engulfment activity with numerous phagosome-like structures 670 within the epithelium. Bar; $10 \mu \mathrm{M}$

671 (B,C) Autophagosomes in WT luminal cells; Note mitochondria in autophagosomes (B; 672 arrow).

673 (D) Autophagosmes and phagosomes containing milk lipids in WT cells. Bar; $2 \mu \mathrm{m}$.

674 (E) Phagosome forming around engulfed milk in WT cells. Bar; $2 \mu \mathrm{m}$.

675 (F) Lipid droplets associated with WT dead cells within the epithelium and shed into the 676 lumen. Bar; $5 \mu \mathrm{m}$.

677 (G) Rac1-/- alveolus showing milk lipid droplets and dead cells in the lumen but no 678 phagosome like structures within the epithelium. Bar; $10 \mu \mathrm{m}$.

$679(\mathrm{H}, \mathrm{I})$ No autophagosomes in Rac1-/- epithelium. Bar; $(\mathrm{H}) 1 \mu \mathrm{m},(\mathrm{I}) 0.4 \mu \mathrm{m}$.

680 (J) Cell necrosis in Rac1-/- epithelium. Bar; $1 \mu \mathrm{m}$

$681(\mathrm{~K}, \mathrm{~L})$ Apoptotic Rac1-/- cells shed into the lumen with nuclear pyknosis $(\mathrm{K})$ and membrane 682 blebbing (L). Bar; (K) $1 \mu \mathrm{m},(\mathrm{L}) 2 \mu \mathrm{m}$.

683 (M-P) Involution day 4 WT cells showing autophagososmes, phagosomes (M) and 684 lysosomes (arrow; N) but Rac1-/- $(\mathrm{O}, \mathrm{P})$ show none. Bar; $(\mathrm{M}, \mathrm{O}) 2 \mu \mathrm{m},(\mathrm{N}, \mathrm{P}) 1 \mu \mathrm{m}$.

685 (Q) LC3 $\beta$ antibody was used to detect autophagic structures in involution day 2 tissues. 686 Note; vesicles in WT epithelium but not Rac1-/.. Krt8/18 antibody was used to mark luminal 687 cells. Bar; $10 \mu \mathrm{M}$ (insert $6 \mu \mathrm{m}$ ). 
(R) Quantitative analysis shows markedly reduced LC3 $\beta$ vesicles in Rac1-/- cells. LC3 positive structures were counted per field. Error bars: $+/-$ SEM of $n=3$ mice. $P=0.0038$.

690 (S) GSEA demonstrating down-regulation of autophagosome and lysosome genes in Rac1-

691 /- glands compared with WT at involution day 2. NES; normalized enrichment score.

692

693 Figure 7: Cell death proceeds faster without Rac1.

694 (A,B) Increased propidium iodide uptake in Rac1-/- cells induced to die through anoikis in culture; (A) fluorescent image and (B) quantification with FACS. (C,D) Apoptotic blebs in WT and Rac1-/- dead cells in culture detected using light microscopy (C) and EM (D). Arrows: membrane blebs. Bar; (C) $5 \mu \mathrm{m}$ (D) $2 \mu \mathrm{m}$.

698 (E-G) EM images of (E) WT and $(F, G)$ Rac1-/- tissues in vivo show apoptotic cells with 699 nuclear pyknosis (E,F) and membrane blebbing (G). Arrow; apoptotic cells are engulfed by 700 the alveolar epithelium in WT glands (E). Bar; (E,F) $2 \mu \mathrm{m},(\mathrm{G}) 1 \mu \mathrm{m}$. (H) Annexin $\mathrm{V}_{-}{ }^{64+}$ and $\mathrm{PI}^{+}$co-labelled $\mathrm{WT}$ and Rac1-/- cells quantified by flow sorting following $1 \mathrm{~h}$ and $5 \mathrm{~h}$ in suspension show more cells proceed to late stage apoptosis/necrosis without Rac1.

704 (I) WT and Rac1-/- cells induced to die through anoikis for $8 \mathrm{~h}$ show reduced numbers of viable cells without Rac1. Cleaved caspase-3 was used to stain apoptotic cells. $n=4$.

(K-N) EM images of WT and Rac1-/- in vivo tissues (K,L) and primary cultures (M,N) show cell necrosis without nuclear pyknosis and organelle release in Rac1-/- cells (L,N). In contrast dying WT cells $(\mathrm{K}, \mathrm{M})$ have an intact cell membrane. Arrow: Nucleus released from necrotic cell without condensation. Bar: (K) $2 \mu \mathrm{m},(\mathrm{L}) 1 \mu \mathrm{m},(\mathrm{M}, \mathrm{N}), 0.5 \mu \mathrm{m}$.

Figure 8: Mammary gland reversibility fails in Rac1-/- involuting glands. 

made available under aCC-BY 4.0 International license.

$714(\mathrm{~A}, \mathrm{~B}) \mathrm{H}+\mathrm{E}$ stain of WT and Rac1-/- glands involuted for $48 \mathrm{~h}$ and then re-suckled for $24 \mathrm{~h}$.

715 WT glands (A) resume a lactation morphology while Rac1-/- (B) show an involution

716 phenotype.

717 (C) Quantitative RT-PCR shows increased casein 2 gene expression in re-suckled WT

718 glands but this is reduced by 18-fold in Rac1-/- glands. Error bars; +/-SEM of $\mathrm{n}=3$ mice. 
bioRxiv preprint doi: https://doi.org/10.1101/2022.02.28.482219; this version posted March 2, 2022. The copyright holder for this preprint

(which was not certified by peer review) is the author/funder, who has granted bioRxiv a license to display the preprint in perpetuity. It is made available under aCC-BY 4.0 International license.

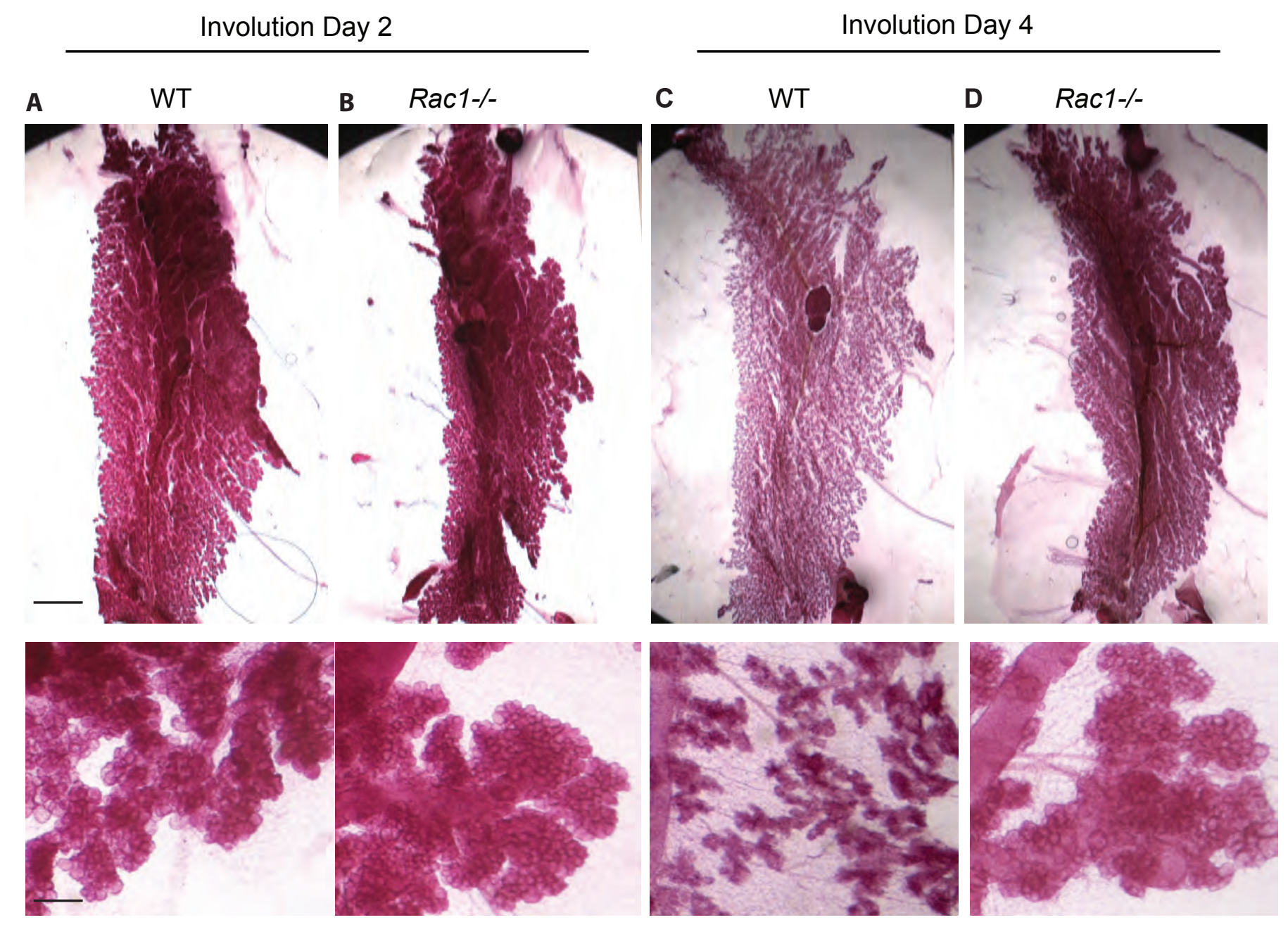

Involution Day 2

Involution Day 4
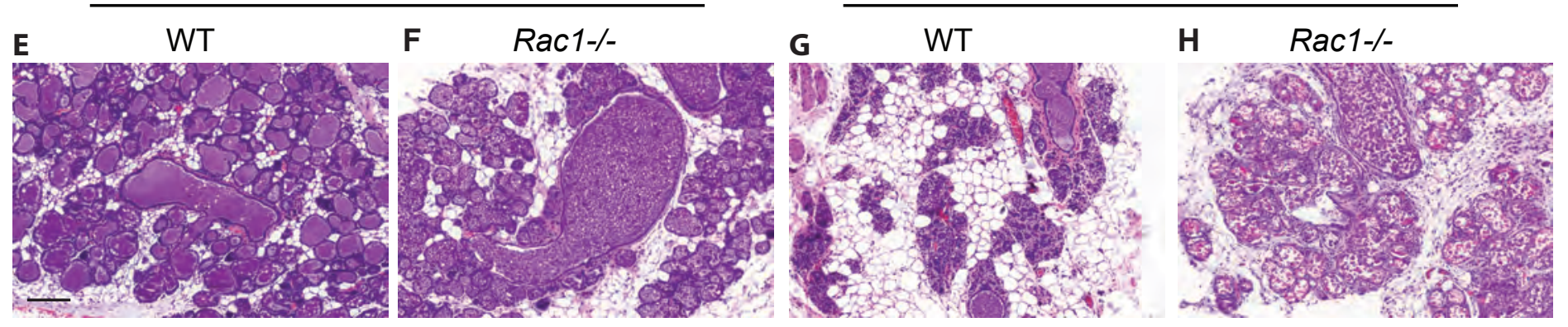

Involution wk 4
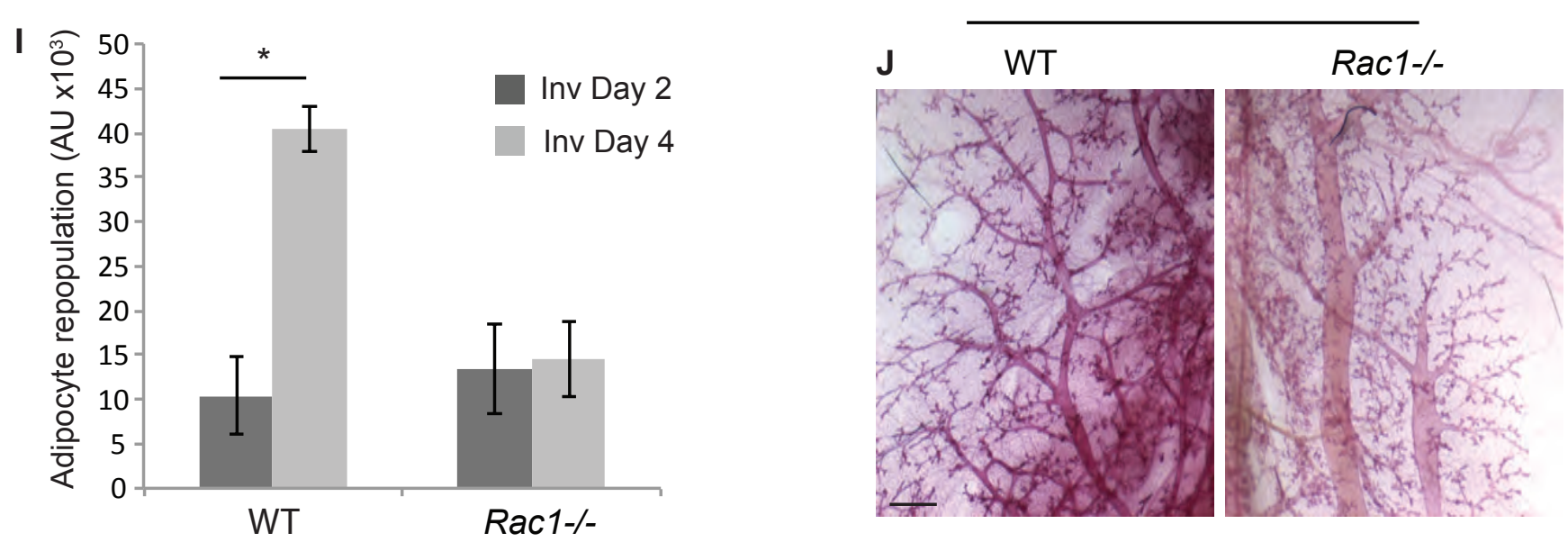
bioRxiv preprint doi: https://doi.org/10.1101/2022.02.28.482219; this version posted March 2, 2022. The copyright holder for this preprint (which was not certified by peer review) is the author/funder, who has granted bioRxiv a license to display the preprint in perpetuity. It is made available under aCC-BY 4.0 International license.
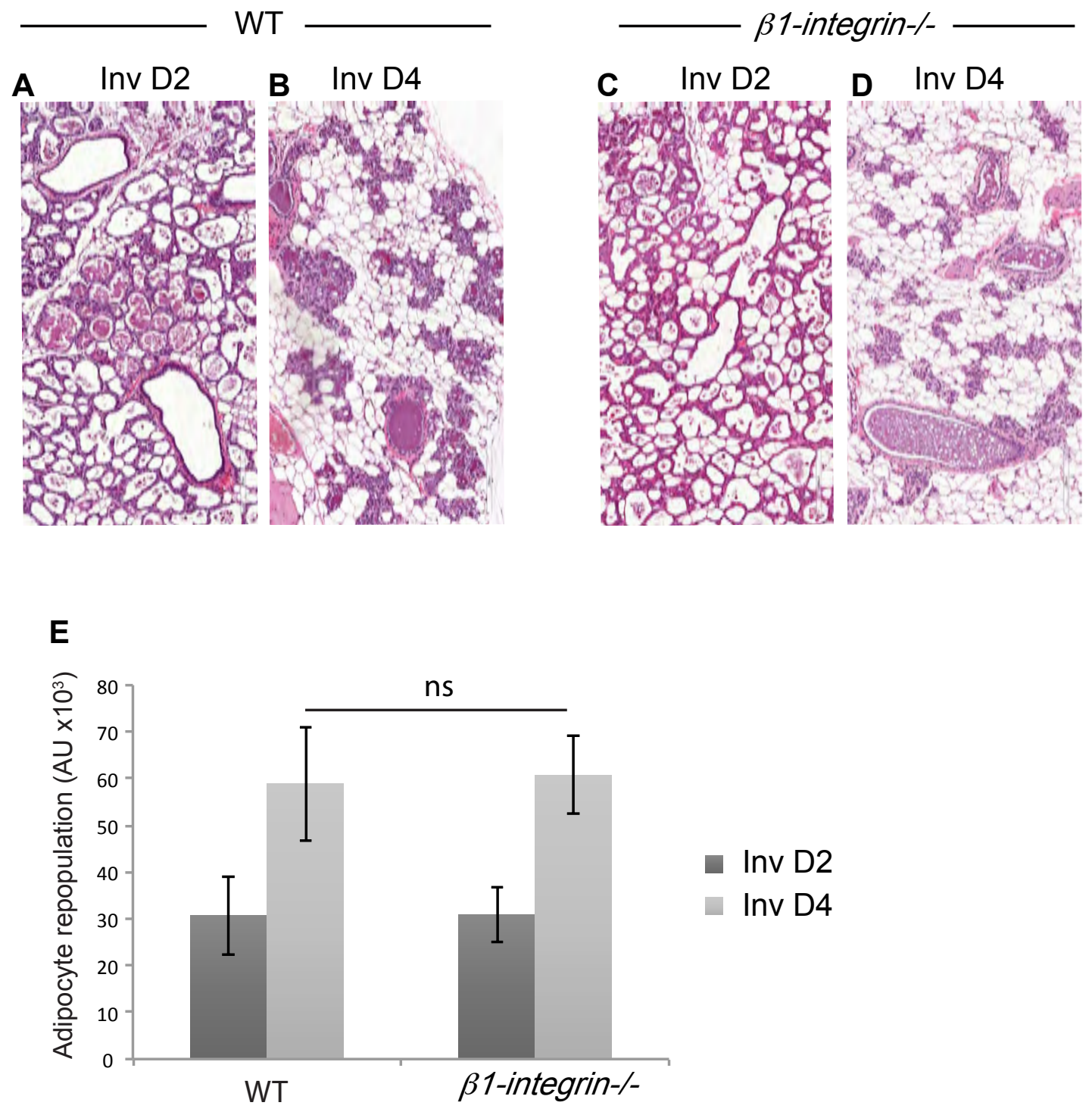

Figure 2 
bioRxiv preprint doi: https://doi.org/10.1101/2022.02.28.482219; this version posted March 2, 2022. The copyright holder for this preprint (which was not certified by peer review) is the author/funder, who has granted bioRxiv a license to display the preprint in perpetuity. It is made available under aCC-BY 4.0 International license.
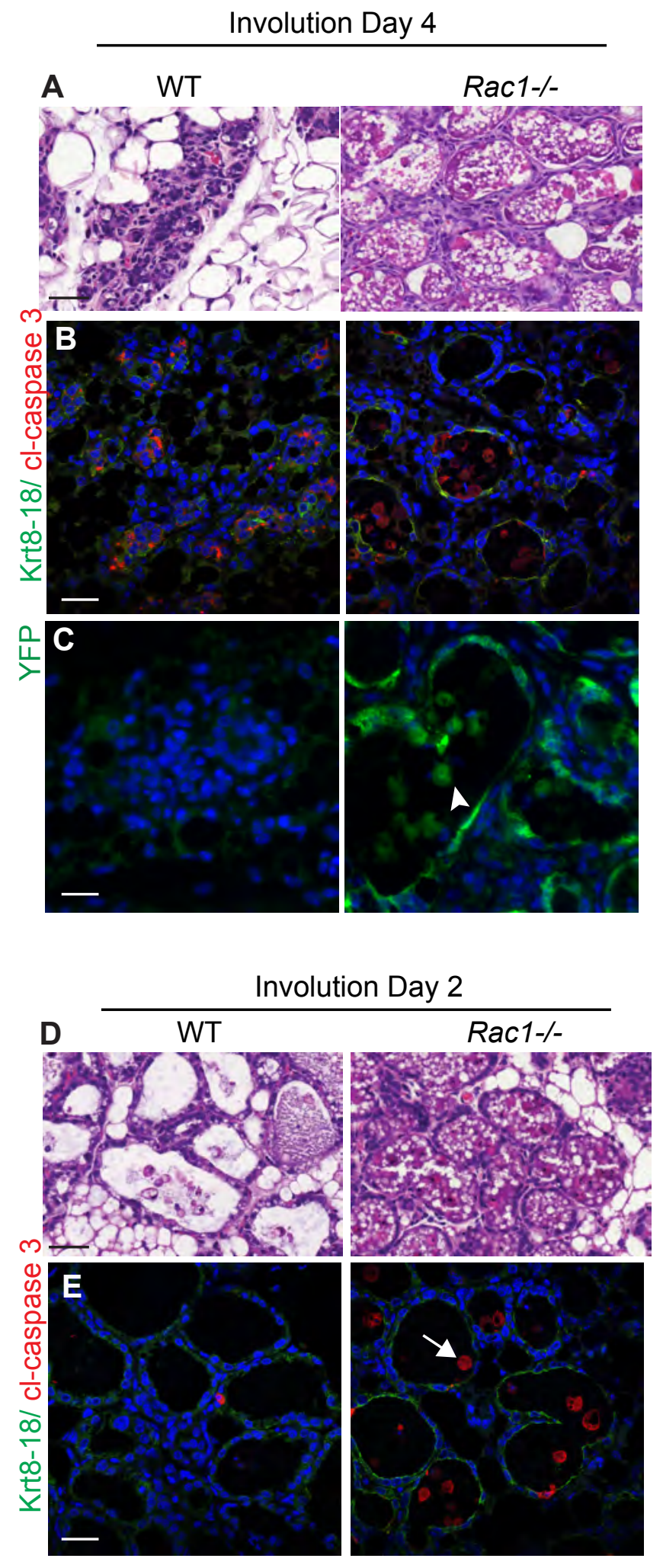
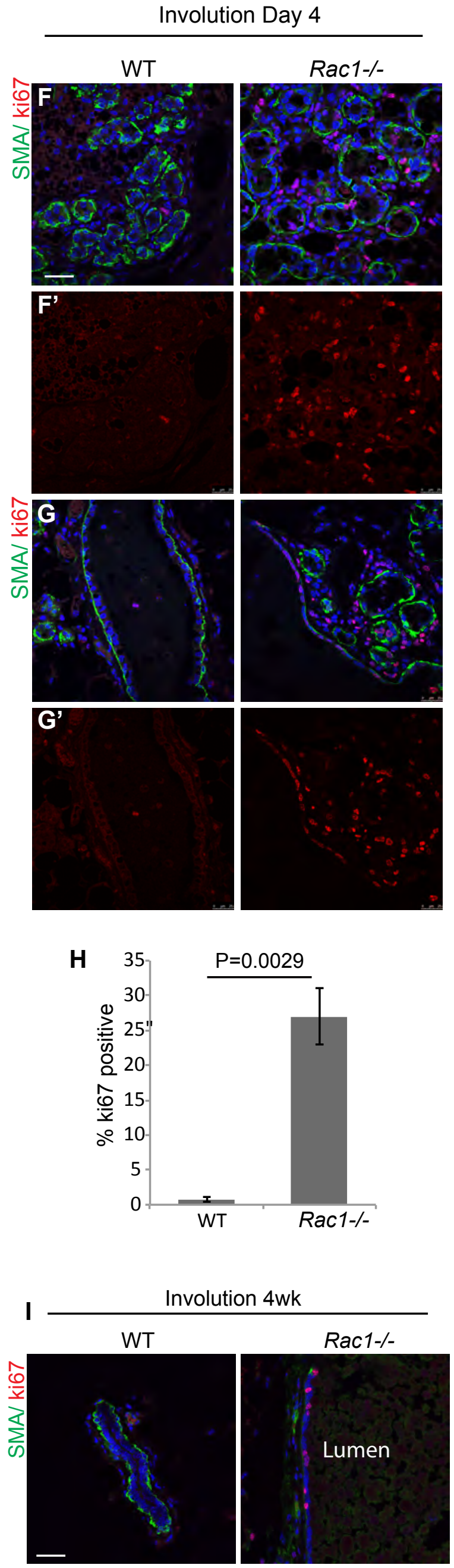
bioRxiv preprint doi: https://doi.org/10.1101/2022.02.28.482219; this version posted March 2, 2022. The copyright holder for this preprint

(which was not certified by peer review) is the author/funder, who has granted bioRxiv a license to display the preprint in perpetuity. It is made available under aCC-BY 4.0 International license.

Pregnancy D18 1st gestation
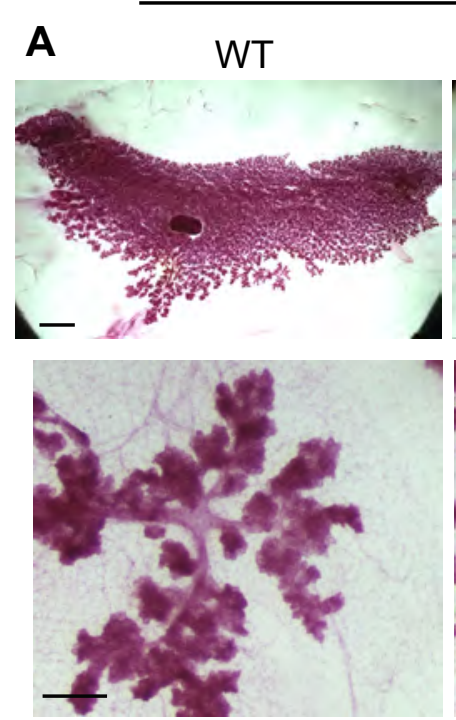
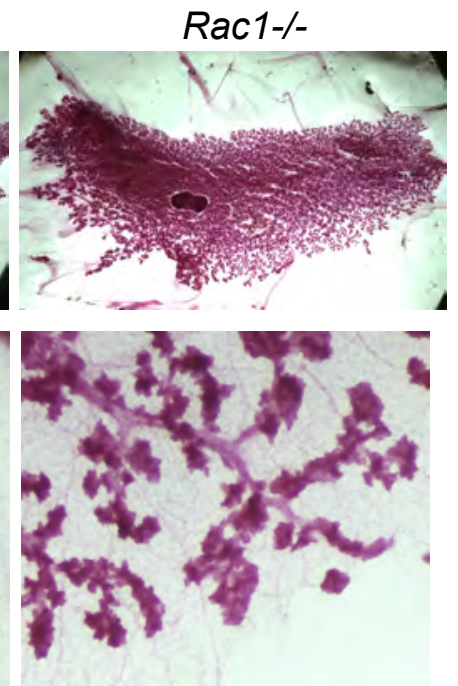

Lactation D2, 1st gestation

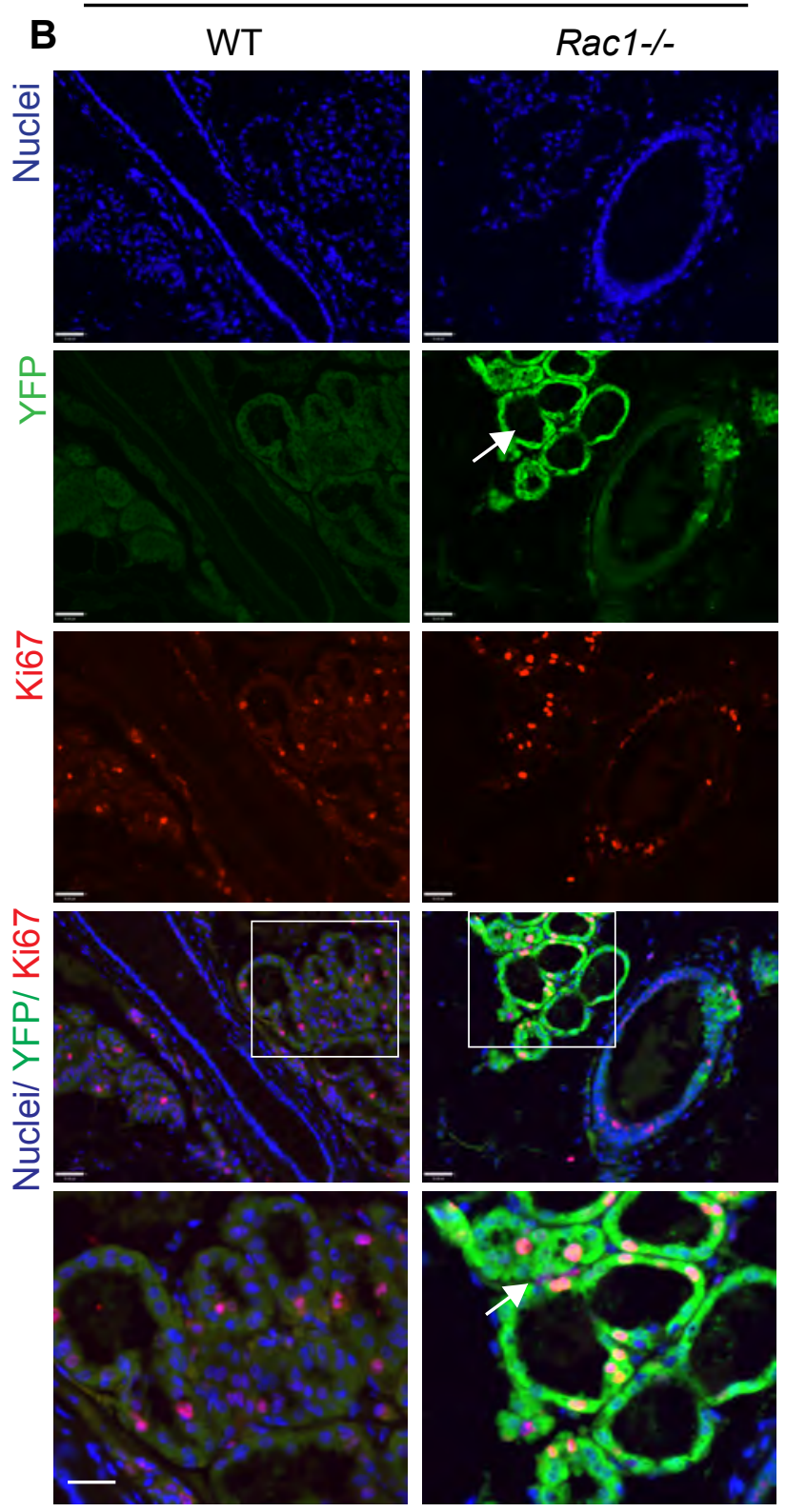

Pregnancy D18 2nd gestation

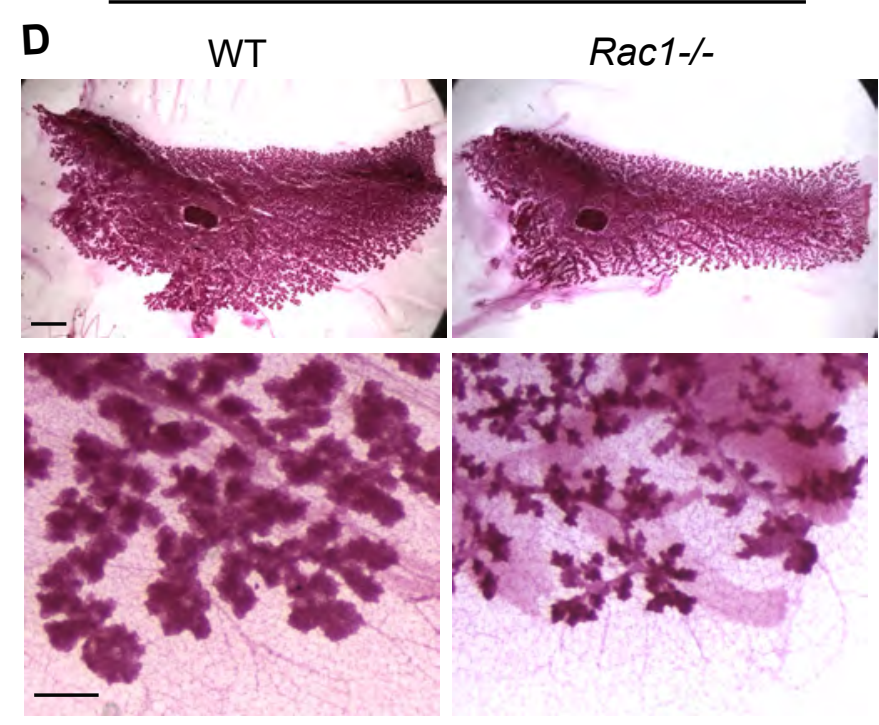

C
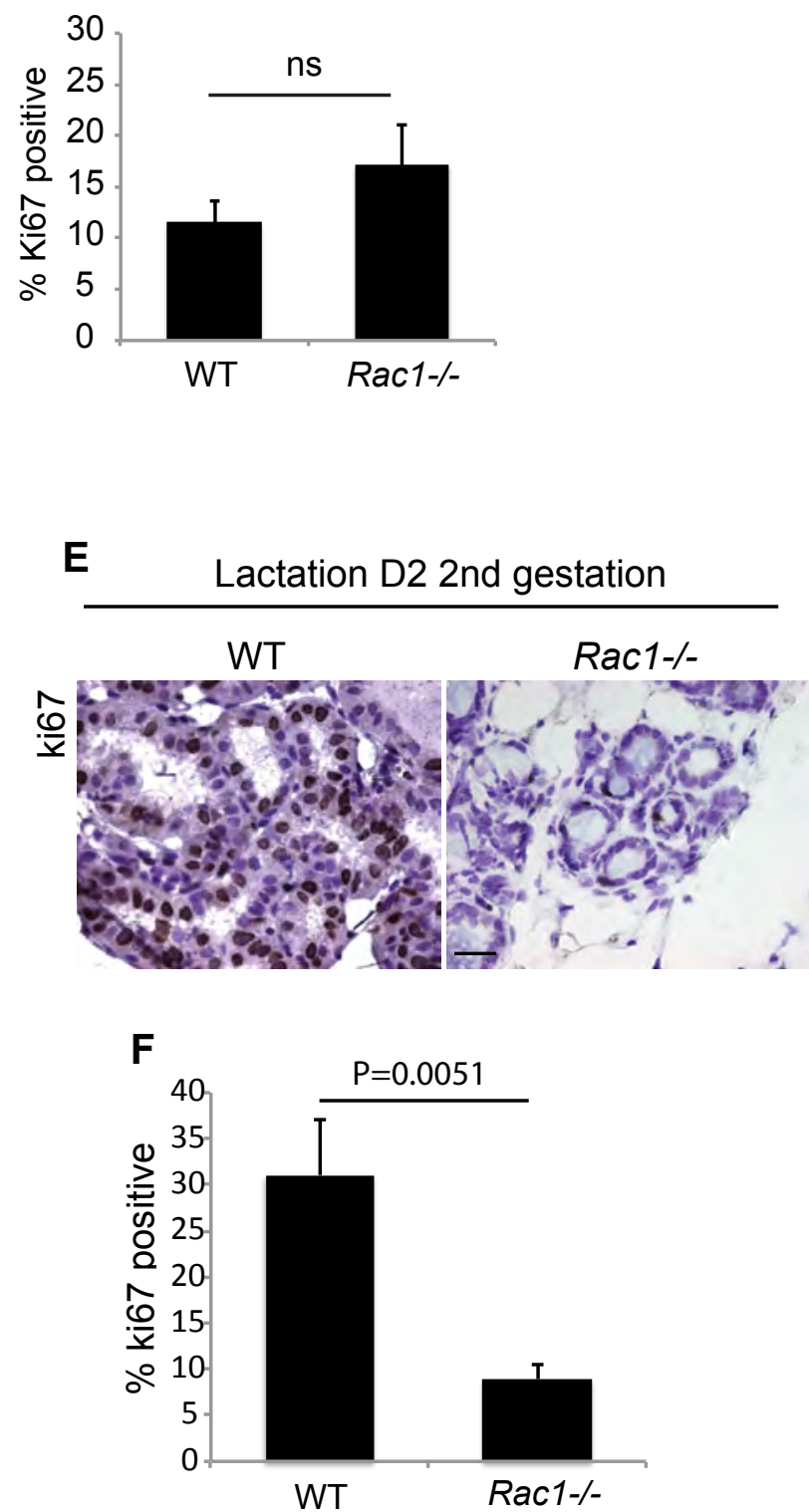

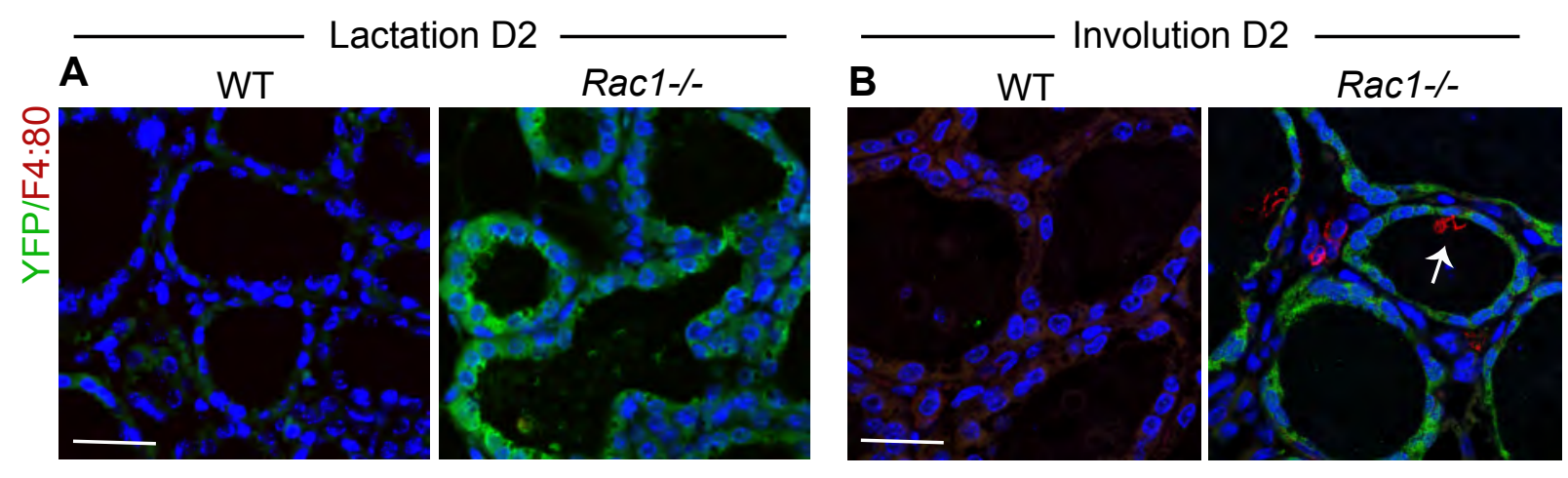

C

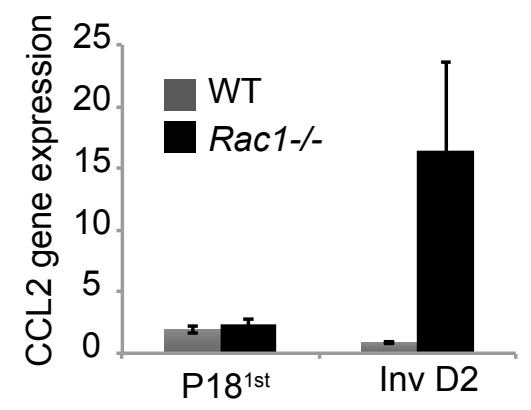

D

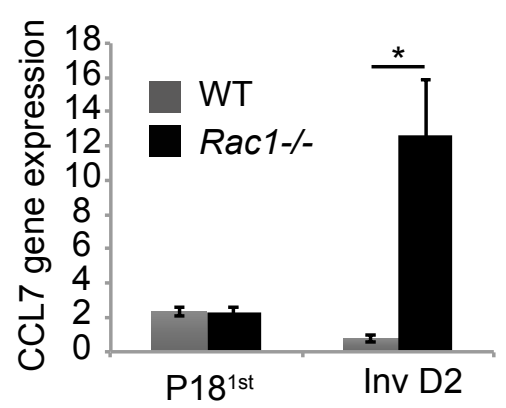

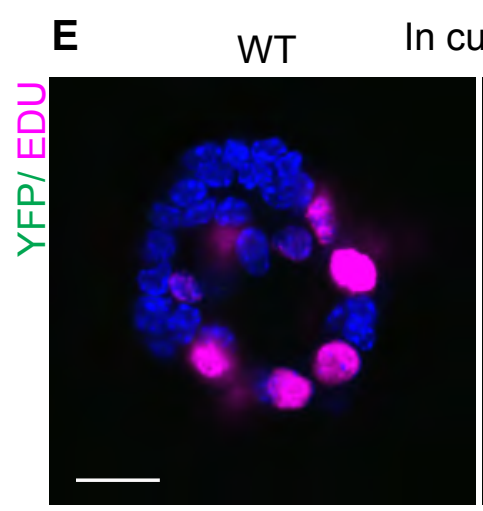

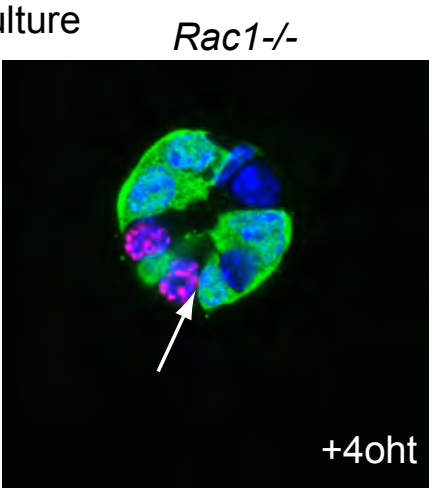

$\mathbf{F}$

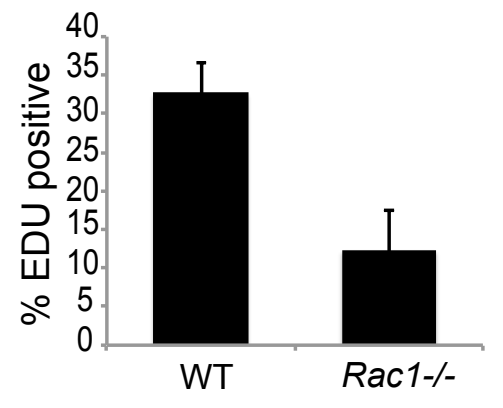

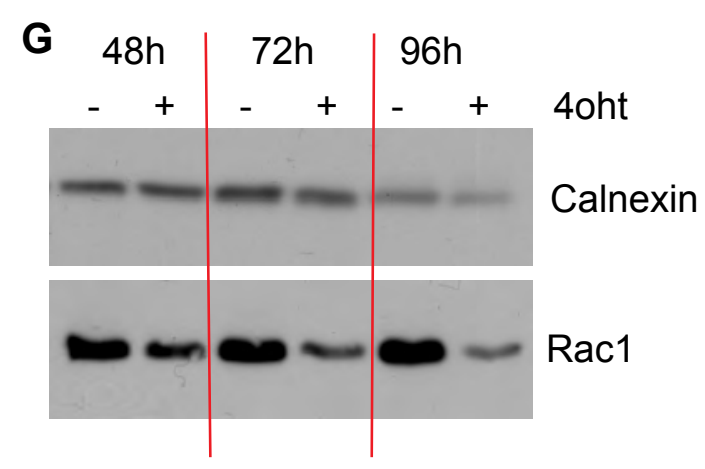

Ductal branching

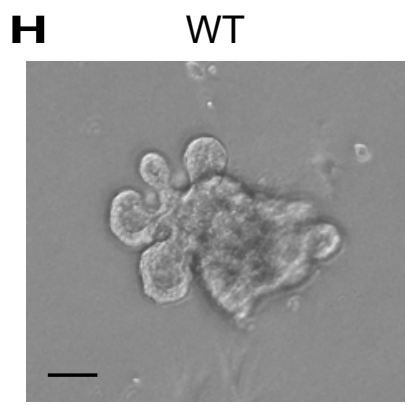

Rac1-/-

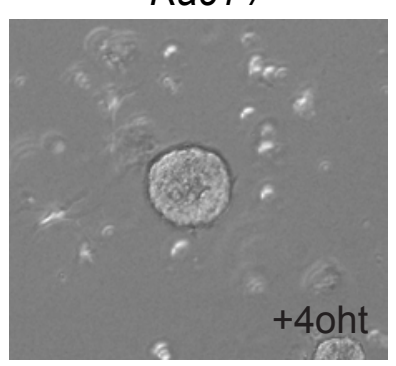


bioRxiv preprint doi: https://doi.org/10.1101/2022.02.28.482219; this version posted March 2, 2022. The copyright holder for this preprint

(which was not certified by peer review) is the author/funder, who has granted bioRxiv a license to display the preprint in perpetuity. It is made available under aCC-BY 4.0 International license.
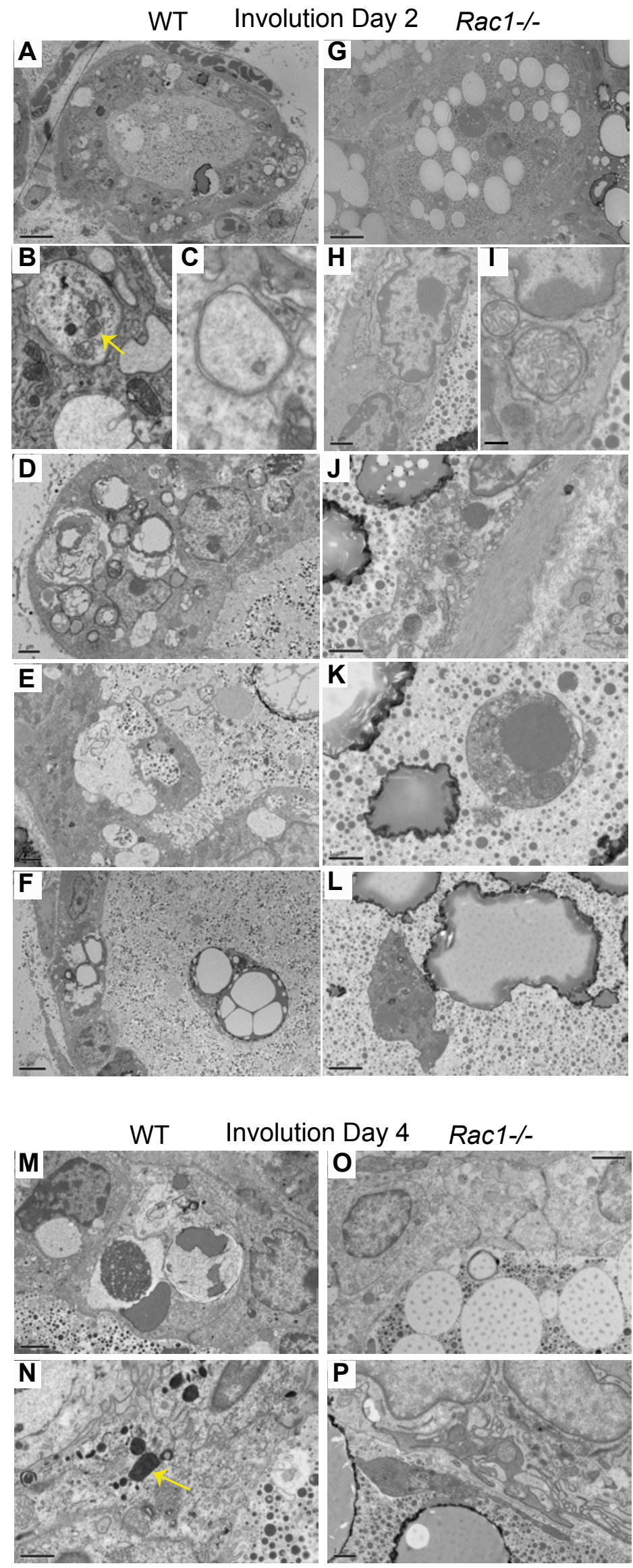
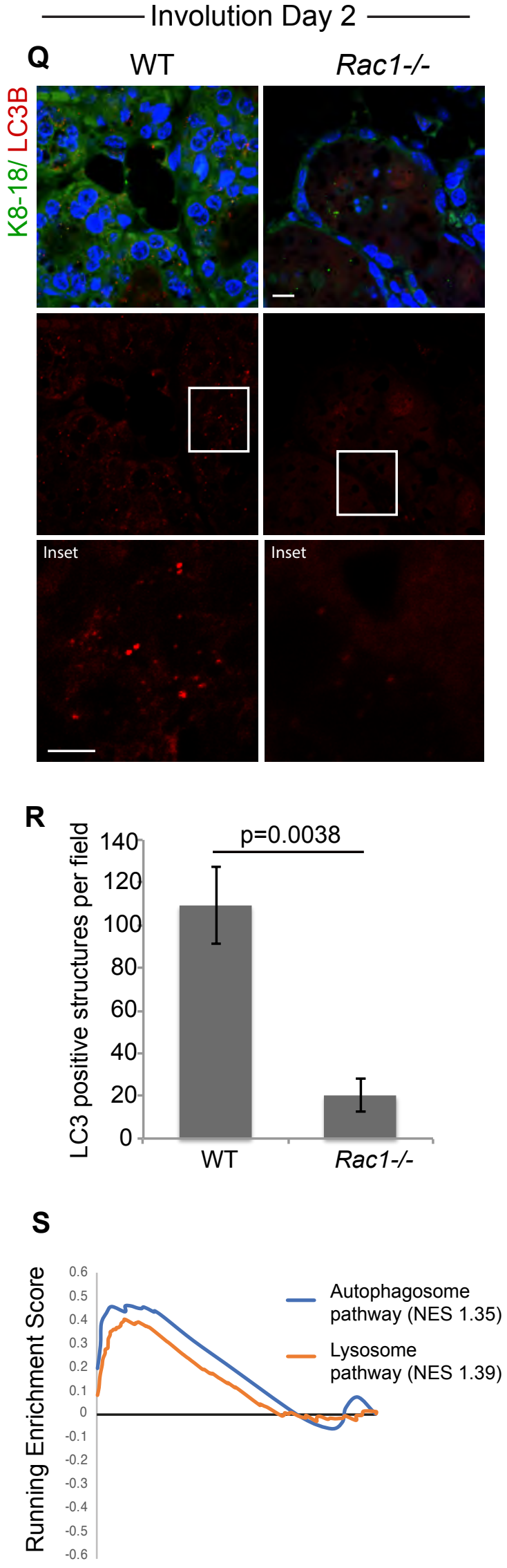

Down in Wildtype Up in Rac1-/vs Wildtype 
bioRxiv preprint doi: https://doi.org/10.1101/2022.02.28.482219; this version posted March 2, 2022. The copyright holder for this preprint

(which was not certified by peer review) is the author/funder, who has granted bioRxiv a license to display the preprint in perpetuity. It is made available under aCC-BY 4.0 International license.

A Control
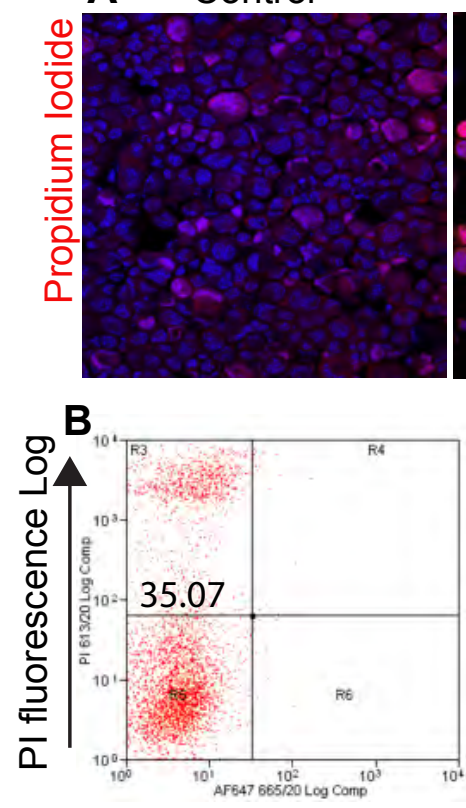

C Control

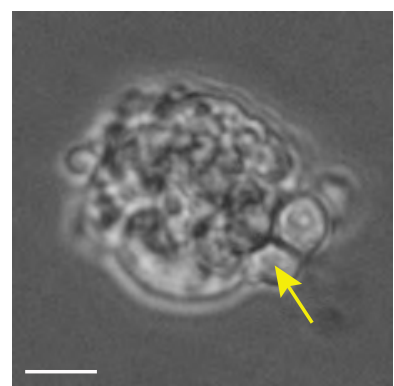

D

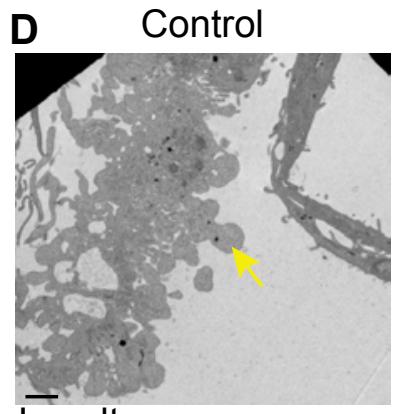

$\overrightarrow{\ln }$ culture

WT
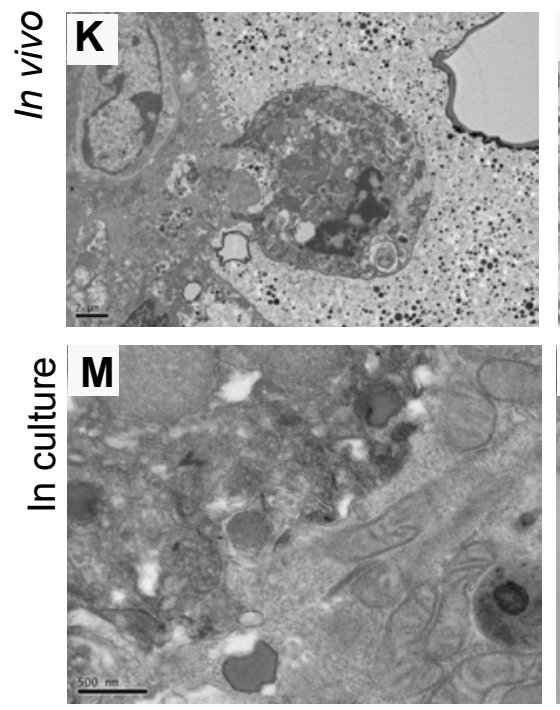

Rac1-/-
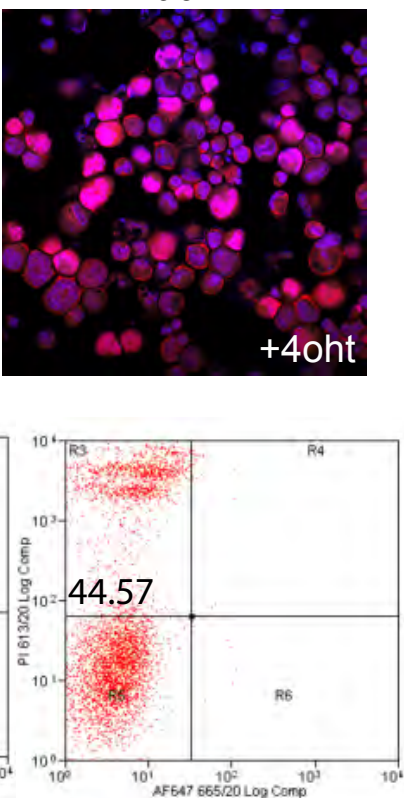

Rac1-/-

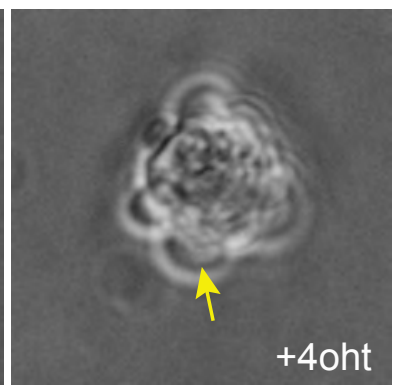

Rac1-/-

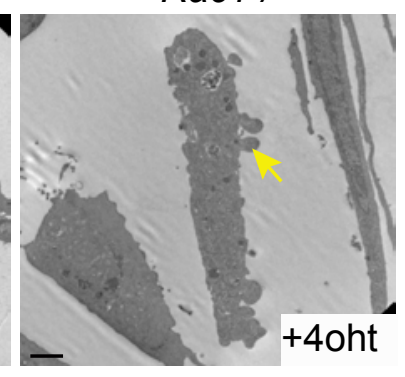

4oht
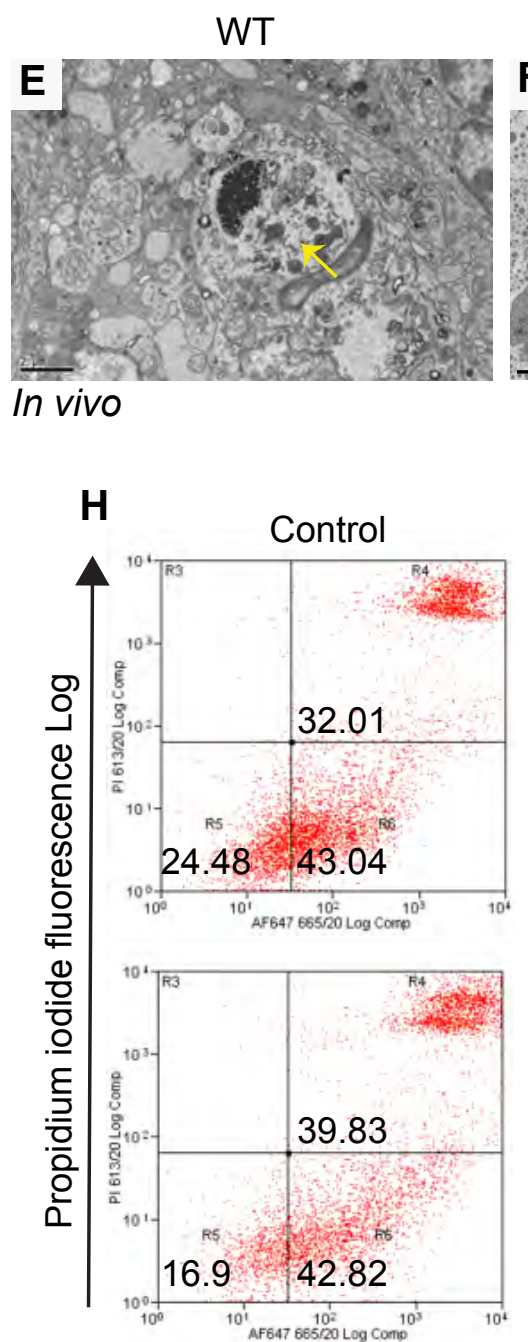
In vivo
H
Rac1-/-

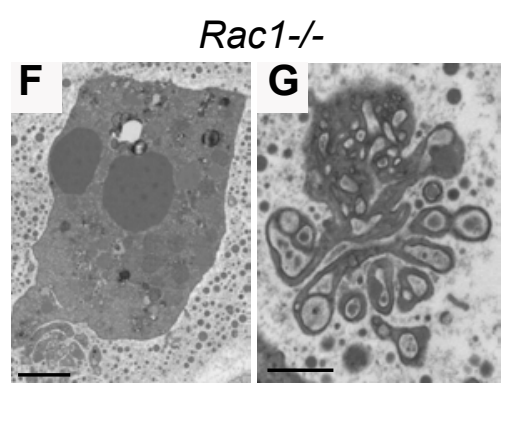

Rac1-/-
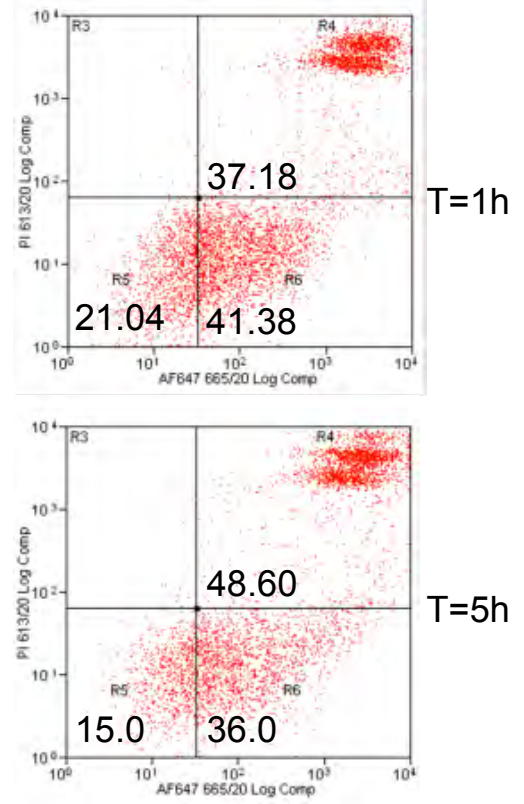

Annexin V fluorescence Log

R5= Live

$\mathrm{R} 6=$ Annexin $\mathrm{V}^{647+}$

$\mathrm{R} 3=\mathrm{PI}^{+}$

$\mathrm{R} 4=$ Annexin $\mathrm{V}^{647+} / \mathrm{PI}^{+}$

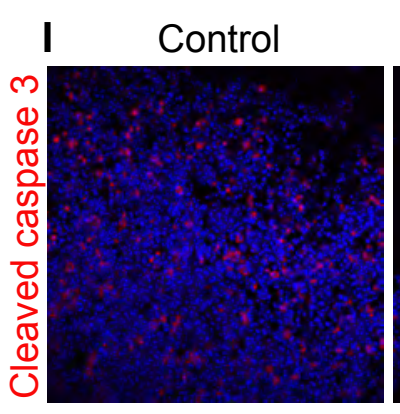

Rac1-/-

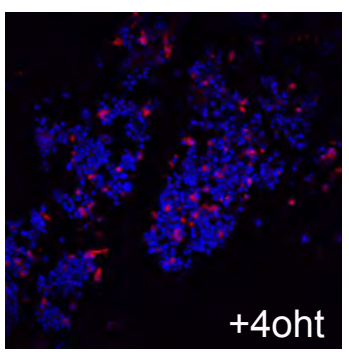

J

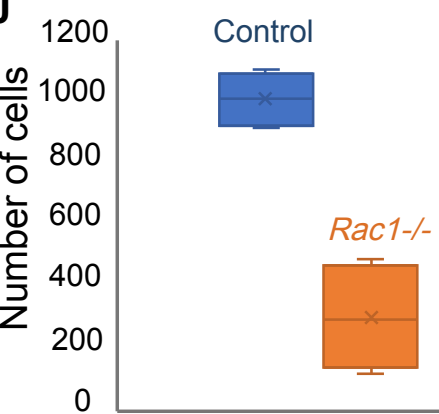


bioRxiv preprint doi: https://doi.org/10.1101/2022.02.28.482219; this version posted March 2, 2022. The copyright holder for this preprint (which was not certified by peer review) is the author/funder, who has granted bioRxiv a license to display the preprint in perpetuity. It is made available under aCC-BY 4.0 International license.

\section{Involution (48h) + Pup return (24h)}

A

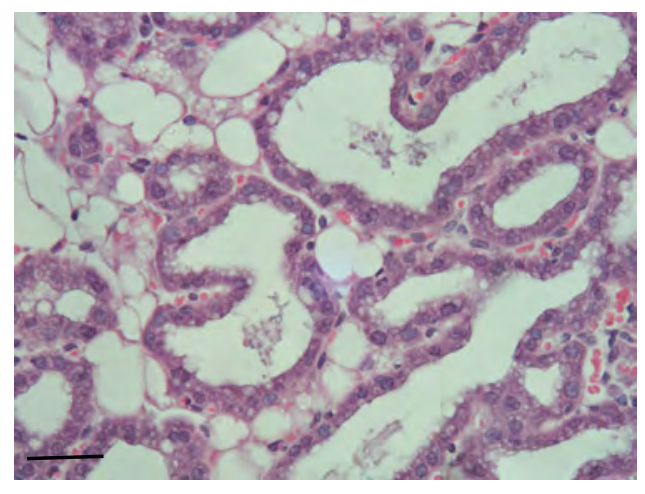

B

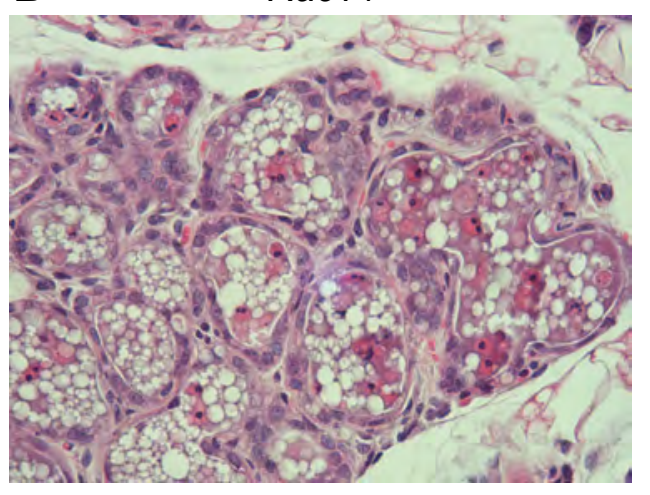

\section{C}

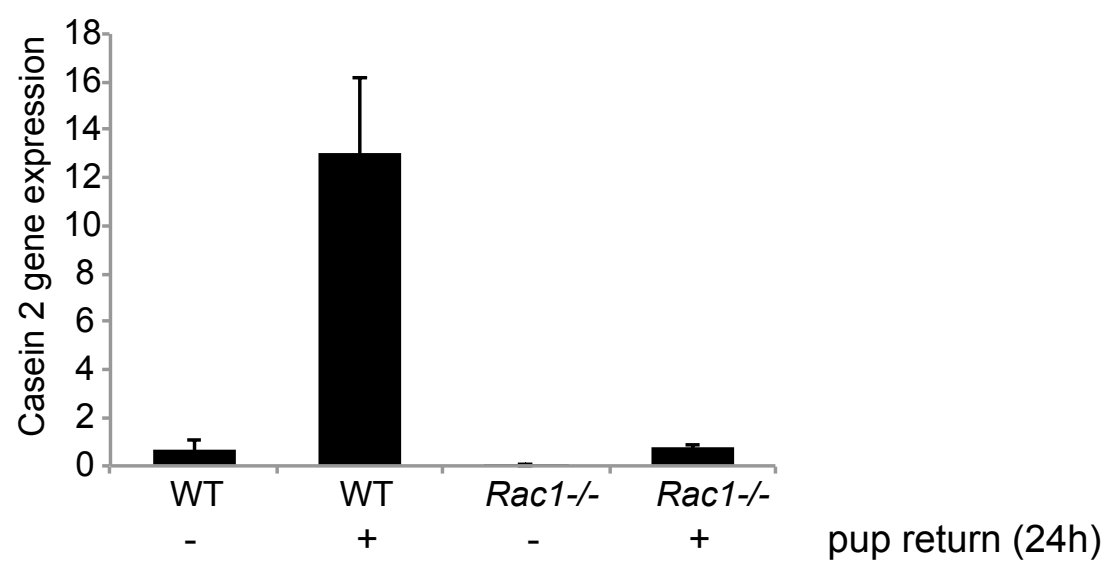

